\title{
Population Growth, Migration, and Changes in the Racial Differential in Imprisonment in the United States, 1940-1980
}

\author{
David J. Harding ${ }^{1, *}$ and Christopher Winship ${ }^{2}$ \\ 1 Department of Sociology, University of California, Berkeley, 410 Barrows Hall, Berkeley, CA 94720-1980, USA \\ 2 Department of Sociology, Harvard University, 33 Kirkland St, Cambridge, MA 02138, USA; \\ cwinship@wjh.harvard.edu \\ * Correspondence: dharding@berkeley.edu; Tel.: +1-510-642-2707
}

Academic Editor: Bryan L. Sykes

Received: 4 February 2016; Accepted: 11 July 2016; Published: 20 July 2016

\begin{abstract}
The proportion of U.S. prison inmates who were black increased dramatically between 1940 and 2000. While about two-thirds of the increase occurred between 1940 and 1970, most recent research analyzes the period after 1970, focusing on explanations such as the war on drugs, law-and-order politics, discrimination, inequality, and racial threat. We analyze the growth in the racial difference in incarceration between 1940 and 1980, focusing on the role of demographic processes, particularly population growth, migration, and urbanization. We implement three analyses to assess the role of these demographic processes: (1) a simple accounting model that decomposes the national trend into population growth, changes in arrests, and changes in sentencing; (2) a model of state variation in incarceration that decomposes the racial difference in incarceration into population change, migration between states with different incarceration rates, and other processes; and (3) race-specific models of within-state variation in incarceration rates using state characteristics coupled with a decomposition of the role of changes in state characteristics.
\end{abstract}

Keywords: race; incarceration; migration; urbanization; population; inequality

\section{Introduction}

The U.S. criminal justice system is said to be in a period of "mass imprisonment" that began in the mid-1970s and now incarcerates more than one in 100 American adults [1-4]. Equally important and frequently commented on is the fact that the current U.S. prison population is overwhelmingly, disproportionately black. Whereas the incarcerated population is now over $50 \%$ black, the U.S. population itself is somewhat less than $13 \%$ black. Thus, the racial composition of prisoners is a defining characteristic of the current mass imprisonment period, with many scholars asserting that the United States' incarceration problem is at its core a racial issue [2,5,6].

Extreme racial disproportionality in the U.S. prison population has not always been the case. Rather, the proportion of the incarcerated population that is black actually grew over much if not all of the 20th century. In 1926, only $21 \%$ of the individuals sentenced to state or federal prison were black, but by the 1990s the comparable figure was over 50\% [7]. This dramatic increase in the incarceration of African Americans occurred during a period that witnessed considerable improvements in their social and economic status, including gains in income, occupational position, and education [8-10]. While the increase in black incarceration was as large during the 1940s, 1950s, and 1960s as during the 1970s, 1980s, and 1990s, almost all recent work has focused on the latter period.

This paper presents analyses aimed at explaining the dramatic increase in the racial difference in incarceration (hereafter referred to as RDI) between 1940 and 1980. We begin with a simple accounting 
model based on Cohen and Canela-Cacho [11] that breaks the national trend into changes in population, arrests, and sentencing. About one-third of the increase in the RDI over this period is due to greater black population growth relative to whites. The remaining increase in RDI can be attributed mostly to differential changes in arrest rates between 1940 and 1960 and to differential changes in sentencing between 1960 and 1980.

In order to further analyze the influences of various factors on white trends in incarceration, black trends in incarceration, and the trend in the RDI, we then model state-level variation in incarceration by race between 1940 and 1980. This model suggests that differential population increase, migration from low to high incarceration states, and increasing incarceration rates in states that experienced population growth and net in-migration together account for about 67 percent of the increase in the RDI between 1940 and 1980.

Finally, in order to further understand racial changes in incarceration, we model black and white incarceration rates over time using state fixed effects and time-varying state characteristics by race, including demographic and economic composition, population growth, migration, urbanization, political context, and segregation. Accounting for demographic and economic composition of the black and white populations in 1940 actually increases the RDI in that year substantially, as the RDI would have been even larger had whites not been much better off than blacks on those dimensions. Between 1940 and 1980 the RDI increases in large part because the relevant characteristics of whites improved more than those of blacks over this period. In fact, controlling for these changes in the demographic and economic characteristics of the two populations actually reverses the residual trend in RDI from increasing to decreasing. In other words, had blacks' demographic and economic characteristics improved as rapidly as whites' throughout the period, the RDI would have declined significantly. Migration, population growth, and urbanization variables explain some of the gap between blacks and whites in 1940 and some of the trend between 1960 and 1980. Controlling for state political context further reduces the RDI in 1940 slightly and plays a minor role in flattening the trend between 1960 and 1970. Controlling for racial segregation further reduces the RDI in 1940 but explains only a small portion of the remaining trend. A set of Blinder-Oaxaca type decomposition exercises pinpoints more precisely the sources and timing of these changes.

We begin by describing racial differences in incarceration in the 20th century and the explanations in the literature that have been offered for this trend. We motivate our analysis by arguing that although the United States experienced considerable population growth, migration, and urbanization during the 1940-1980 period, all of which varied by race, these factors have not been previously considered as explanations for changes in incarceration rates. Our analysis proceeds in three parts. We conclude by summarizing the results and discussing their implications.

\section{Racial Differences in Incarceration in the 20th Century}

Figure 1 reports trends in incarceration by race between 1923 and 2000. The topmost line shows the racial composition of inmates in federal and state prisons and local jails from 1923 to 2000 , based on decennial census data from 1940 to 2000 and a special survey of correctional institutions conducted by the Census Bureau in 1923 [12]. The proportion of inmates who were black appears to be relatively constant or slightly declining between 1923 and 1940 (though caution should be exercised in interpreting this trend since it is based on only two time points and we know little about the quality of the 1923 data). The increase in the RDI accelerates gradually from 1940 to 1970, with the steepest increase during the 1960s. The slowest increase is during the 1970s and 1980s, and the proportion of 
inmates who were black actually declined slightly during the 1990s. ${ }^{1}$ The remaining two lines show the black and white incarceration rates. These show the now well-documented increase in incarceration after 1980, which affected blacks much more dramatically. However, it is striking that the RDI increased between 1940 and 1980 despite relatively flat incarceration rates for both racial groups. In the remainder of the paper we focus on the period between 1940 and 1980, the period prior to the impact of the policy changes related to the "war on drugs" and determinant sentencing that have been the focus of previous research. The question this paper addresses is, what factors might account for the changes in the racial difference in incarceration between 1940 and 1980 ?

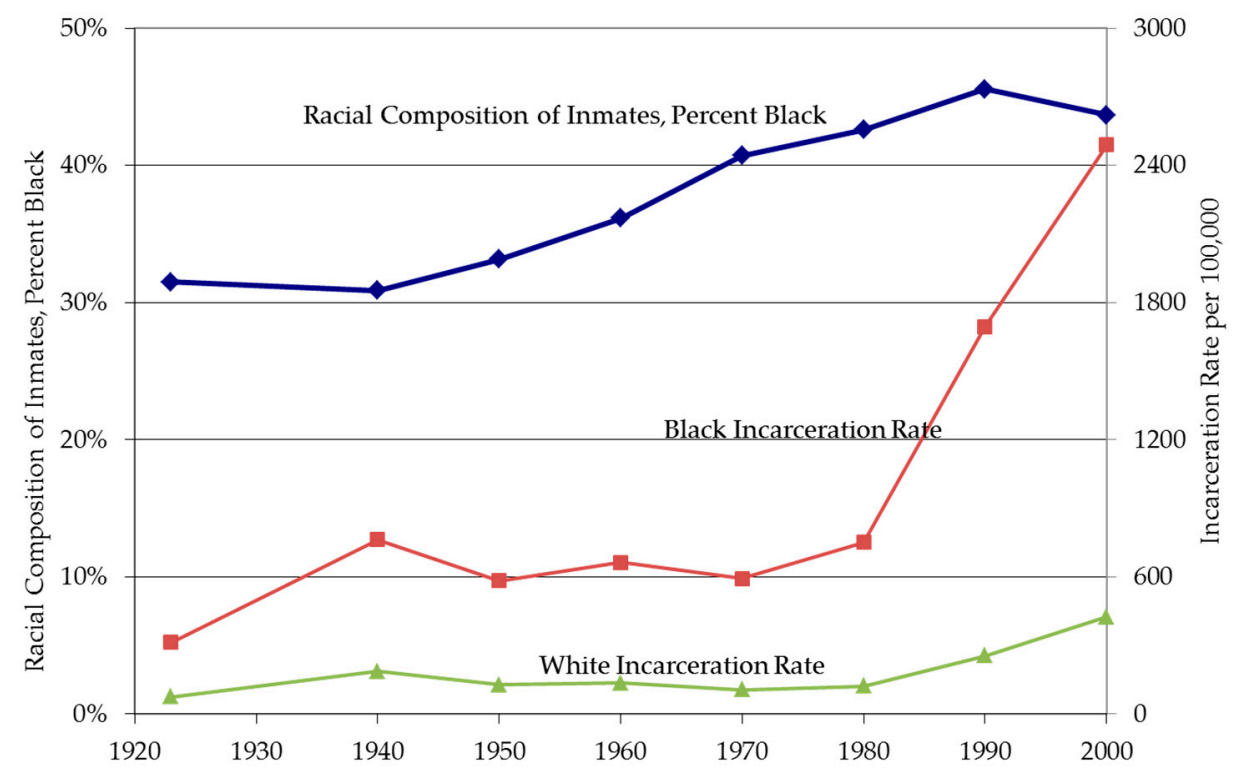

Figure 1. Incarceration in prisons and jails, by race.

In the remainder of this section, we discuss existing scholarship on race and the criminal justice system that provides possible explanations for the rise in the RDI between 1940 and 1980. We discuss explanations that are specific to the 1940-1980 historical period, the focus of this study, and explanations that have been offered for the increasing RDI in later periods. It is important to consider whether explanations developed to account for the more recent rise in the RDI might also account for the rise during the 1940-1980 period. The explanations we discuss generally center conceptually on either (a) the economic and demographic causes of changes in crime rates or (b) the punitiveness of the criminal justice system. While it is important to distinguish such processes conceptually, key social changes over our period of interest, such as the northern migration and urbanization of the black population, are thought to be related to both types of processes.

\subsection{Economic and Demographic Change}

We begin with economic and demographic changes that might have impacted incarceration rates through their impact on crime rates. One of the most significant demographic changes in the middle of the 20th century was the "Second Great Migration" of blacks from the rural and urban South to the urban North, a process that accompanied the continued transformation of the economy from

1 The top line of Figure 1 contains the number of black inmates divided by the total number of inmates of any race. The proportion of inmates who were neither black nor white increased steadily after 1970 . While only $2.2 \%$ of inmates were neither black nor white in 1970, this percentage increased to $8.5 \%$ in 1980, 9.0\% in 1990, and $11.0 \%$ in 2000 . These numbers presumably almost entirely reflect the increasing numbers of Hispanic/Latino inmates beginning in the 1970s. Trends are comparable if we use the ratio of black to white inmates. In 2000, the black count is those reporting black alone as their race and the white count is those reporting white alone. 
agriculture to manufacturing, particularly in the period after World War II [13]. Between the 1930s and 1960s much of the black population moved north and into urban areas. Jaynes and Williams [10] have speculated that long-term increases in black incarceration rates in this century are due to the effects of the Great Depression and the social dislocation caused by World War II, as well as the subsequent urbanization of blacks with the decline of Southern agriculture. Urban areas have consistently had higher crime rates $[14,15]$, and during much of the 20th century the racial differential in incarceration has been considerably larger in the North than in the South, although that difference declined in the later part of the century [16-20]. As a result, the migration of blacks off the farm to cities in the North and South may have substantially contributed to increases in the overall RDI.

Economic changes that have disadvantaged blacks may also play a role in changes in the RDI. Duster has argued that economic changes particularly impacted black youth, resulting in increased contact with the criminal justice system [21]. During much of the period in which we are interested, youth unemployment rates rose considerably, in great part because of declines in agricultural employment [22], in part because of increases in school enrollment and military enlistment [23], and in part due to declines in manufacturing in inner cities [24]. Manufacturing employment, which provides relatively high wages for low-skilled work, is negatively associated with crime [25]. Yet many studies have examined the effects of unemployment on crime rates with mixed findings [15,26-29]. In addition, Myers and Sabol [27] have fit time series models to the 1880 to 1980 period and have shown that the rate of incarceration of blacks in the North is positively associated with unemployment rates and negatively associated with manufacturing output.

Several other demographic changes during the 20th century should also be considered. The migration of blacks from the South to the urban North was also accompanied by an increase in racial segregation, as blacks were restricted to ghetto neighborhoods in northern cities by government policies and white violence [30]. As Massey and Denton [30] argue, segregation coupled with higher poverty rates among blacks concentrates blacks in poor neighborhoods, potentially increasing crime in black communities [25,31-34]. To the extent that racial segregation concentrates poor blacks, and concentrated disadvantage leads to lower social control, segregation may increase crime among blacks [35-38]. The geographic concentration of blacks may also change the character of policing in black communities to focus on arrest rather than crime prevention or hide the consequences of increased incarceration from whites.

Within-race income inequality is another possible explanation. Even as the economic and social status of the average black individual has increased, income and educational inequality has grown within both the black and white populations [10,39]. According to Wilson [24], the growth of the black middle class and their exit from inner-city communities weakened the institutional foundations of those communities, leading to a decline in social organization and social control in ghetto neighborhoods. LaFree and Drass [40] show that changes in intra-racial income inequality predict changes in arrest rates for robbery, burglary, and homicide among both blacks and whites between 1957 and 1990 and that increased education among blacks is associated with higher black arrest rates, but only during periods of rising inequality. ${ }^{2}$

Finally, the number of single-parent households increased over most if not all of this period, with particularly large increases in the 1970s and 1980s [23,44]. The conjecture is that children growing up in single-parent households are more likely to be involved in crime. In fact, a number of studies have demonstrated the strong effects of single-parent households on crime rates, especially for juveniles $[26,37,45,46]$, making this an important possible cause of increases in the racial differential in imprisonment.

2 Jacobs and Helms [41] and Jacobs and Kleban [42] find that overall economic inequality is associated with greater overall incarceration rates. Jacobs and Richardson [43] find that higher overall economic inequality is also associated with higher homicide rates. 


\subsection{Race, Politics, and the Punitiveness of the Criminal Justice System}

Another strand of the literature focuses on the enduring link in American political culture between blackness and criminality, as well as the longstanding practice of using the criminal justice system as a tool for the social control of blacks and their labor [47-49]. For example, there is a branch of literature that examines incarceration rates in the South after the Civil War, when imprisonment replaced slavery both as a mechanism of social control and as a way of recreating a captive labor force through the use of chain gangs (Hawkins [17] and Sabol [19] provide short reviews of this research). The punitiveness of the criminal justice should be examined both with regard to arrest and with regard to sentencing, as Sabol [19] demonstrates that at the state level changes in the relative arrest rates cannot fully explain changes in the racial differential in incarceration.

The dominant account in this literature views the increasing punitiveness of the criminal justice system as a backlash against black gains that stemmed from the Civil Rights movement and white fears following the urban unrest of the 1960s. Such fears were fomented and capitalized upon by Republican politicians such as Barry Goldwater and Richard Nixon, who ushered in an era of "Law and Order" politics $[4,6,47,48,50]$. These political actors, drawing upon the longstanding association between race and crime in American political culture, reframed urban unrest by linking it to violent crime and racial threat more generally in a move to separate middle and working class whites from the Democratic party coalition [51].

A recent wave of political science research adds two important modifications to this dominant account. One modification is that violent crime rose dramatically between the mid-1960s and mid-1970s, and as a result middle and working class blacks were also supportive of a more punitive criminal justice system [51-53]. This links the political story to the above discussion of within-race inequality. The second modification is that the institutional and cultural roots of the expansion of the criminal justice system were developed before the era of Law and Order politics. The 1968 Safe Streets and Crime Control Act established the Law Enforcement Assistance Administration, which provided resources for the expansion of the criminal justice bureaucracy and the state capacity to punish, developed a constituency of professionalized criminal justice actors with a stake in crime control policy and punishment, and cemented federal-state interconnections around crime policy that would be necessary for the implementation of federal policies at the state and local levels [49,54]. Moreover, Murakawa argues that the cultural roots of a more punitive criminal justice system were fomented by both "race liberals" and "race conservatives", with race liberals viewing a stronger, more professional criminal justice system as necessary to defend blacks from white violence and discrimination, and race conservatives viewing the criminal justice system as a protection against violence by blacks and a bulwark against the Civil Rights movement [49].

Empirical research attempting to link these shifts in political context to changes in the criminal justice system has focused on two processes. Most of this research concentrates on the period after 1970 and the rise of Law and Order politics. One focus is discrimination within the criminal justice system. Blumstein [55,56] and Tonry [6] describe the considerable increase in the relative rate of drug arrests and subsequent changes in imprisonment for nonwhites since the mid-1970s. Sampson and Laub [57], Feeley and Simon [58], and Tonry [6] have all argued that the "War on Drugs" has become a "War on the Black Underclass", resulting in increasingly racially discriminatory practices by the judicial system. Jencks [59] and Sampson and Laub [57] show that during the 1980s the racial differential in serious crimes declined. Langan [60] provides evidence for increased discrimination between 1973 and 1982, showing increases in racial differential relative to changes in the racial differential in crime. ${ }^{3}$

3 The question of racial discrimination is a complicated one. At times researchers have argued that the criminal justice system is more lenient in its treatment of blacks because the victims of crimes committed by blacks are typically black (see Mann [15] for a discussion of the extensive literature on capital punishment related to this issue). At other times researchers have argued that there is discrimination in the form of more severe treatment of blacks. There is also evidence that other forms of discrimination have lessened or at least remained the same over the last several decades [10]. 
A second and related focus is changes in policy, particularly greater likelihood of sentencing to prison for drug, violent, and repeat offenders [2,61,62]. Using data from the 1970s to the 1990s, Jacobs and his colleagues have argued that the rise of law-and-order politics by the Republican party has contributed to increased incarceration of minorities, showing that Republican strength is related to state variation in black incarceration rates and local variation in racial differences in sentencing [2,41,46,63-65]. Black arrest rates are related to the degree of racial threat [66], as are rates of capital punishment [67] and support for liberal policies [68]. Incarceration rates for minorities and police strength are both higher in states or cities with more minorities [2,41,63-65,69]. However, Stucky, Heimer, and Lang's [70] finding that the relationship between partisan politics and incarceration depends on the degree of electoral competition suggests that political context may not necessarily have the same effects in all time periods. We know of no research that has directly examined these relationships in earlier periods.

In sum, existing research suggests a number of factors that might account for the increase in the RDI between 1940 and 1980, including population growth, migration, urbanization, segregation, employment, age composition, within-race inequality, single parenthood, education, and political context. The analyses that follow investigate racial differences in incarceration between 1940 and 1980, examining these factors. Although our primary interest is in demographic factors, particularly urbanization and migration, we consider other factors as well because they are possible complementary explanations.

\section{Data and Methods}

Our analysis is divided into three parts, each building upon the next. The first analyzes national data on trends in population size, arrests, and sentencing by race. The second uses state-level data to decompose the change in the RDI into components due to changes in population size, migration between states, and changes in state incarceration rates. The third, also employing state-level data over time, examines specific hypotheses about the predictors of black and white incarceration rates and whether such predictors can account for the trend in the RDI using Poisson regression. We discuss the data and methodology for each in turn.

\subsection{Part I: A National Accounting Model}

We first present an ideal model, and then discuss the model we can actually estimate with the data at hand as well as its limitations. Ideally, imprisonment should be analyzed as a multistage process of which incarceration is the final outcome. First (in most cases, presumably), a crime must be committed. A person then is at risk of being arrested, and finally may be sentenced to serve time. To approximate this process, we propose a simple accounting model containing the following quantities:

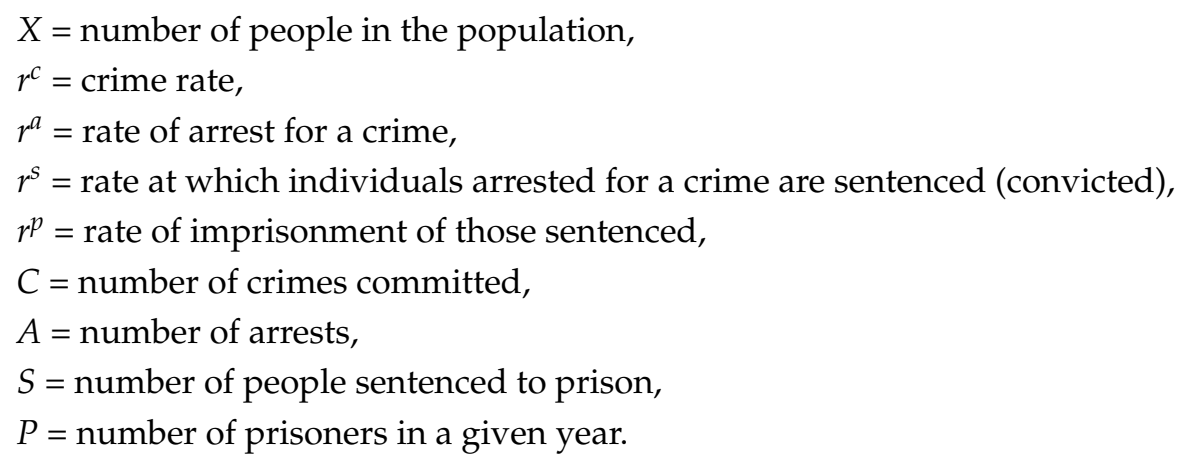

Finally, define: $r^{a c}=r^{a} r^{c}, r^{s a c}=r^{s} r^{a} r^{c}$, etc. Then:

$$
\begin{gathered}
C=r^{c} X \\
A=r^{a} C=r^{a c} X
\end{gathered}
$$




$$
\begin{gathered}
S=r^{s} A=r^{s a} C=r^{s a c} X \\
P=r^{p} S=r^{p s} A=r^{p s a} C=r^{p s a c} X
\end{gathered}
$$

We can think of this model as applying to an entire population and the overall crime rate, or we can think of it as applying to specific subpopulations and/or particular crimes. In addition, "sentence" to prison can be understood as broadly capturing any entry into prison, whether for new sentences or violations of probation or parole. In other words, by sentencing we mean both front-end and back-end sentencing. Sentence length is also implicitly included in the sentencing component of the model (see also footnote 5 below). Obviously, it would be desirable to break sentencing as we have defined it into its constituent parts, but the data needed to do so do not, as far as we know, exist.

The model needs to pertain to a specific period of time. Here we assume that the period is one year. There are then three aspects of this model that are potentially unrealistic simplifications. First, individuals may commit more than one crime each year, as some individuals surely do, and they may be arrested more than one time, as some individuals surely are. The model, however, assumes that committing a crime, being arrested for the crime, and being sentenced all take place in a given year. If year-to-year changes in these rates are small, as we would generally expect, this poses no problem. A second simplification in this model is that if an individual is in prison for part of the year, during that time s/he does not have the same potential for committing crimes and being arrested. Thus the model does not take into account the potential incapacitation effects of imprisonment. For simplification, we will also assume that there is a linear relationship between the number of individuals sentenced to prison in a given year, $S$, and the number of individuals in prison, $P .4$

The advantage of this accounting model is that it can be used to decompose the different components of change in the overall number of individuals in prison. Equation (4) above implies:

$$
X r^{c} r^{a} r^{s} r^{p}=P
$$

The number of people in prison, $P$, is the product of the number of people in the population, $X$, times the crime rate, $r^{c}$, times the arrest rate, $r^{a}$, times the sentencing rate, $r^{s}$, times the imprisonment rate, $r^{p}$. In accounting for change, it is natural to think about how different factors affect the different rates in this model. In order to simplify our decomposition it is useful to put Equation (5) in log form so that we have an additive instead of multiplicative equation, giving us:

$$
\ln X+\ln r^{c}+\ln r^{a}+\ln r^{s}+\ln r^{p}=\ln P
$$

We can think of changes as potentially acting on any one of the five components to produce change in $\ln$ P. Similarly, we can decompose the racial difference in $\ln P$ into differences in the above five components, and we can break down the changes in the racial difference in $\ln P$ into changes in the racial differences in each of the five components. Below we do this using national data.

Unfortunately, existing data do not allow for measurement of all the components of the model, necessitating some simplifications that lead to limitations of the analysis. We have measures of neither

4 In reality, the number of people in prison at any time is a function of the number of prisoners admitted in prior years and their actual sentence lengths. Specifically, if we let $S_{t}$ be the number of people sentenced in year $t, P_{t}$ be the number of people in prison at time $t$, and $r_{t-i}^{p>i}$ be the proportion of the individuals who have prison terms greater than $i$ years which start in year $t-i$, then (assuming that prison terms are in yearly increments) the number of individuals in prison at time $t$ is:

$$
P_{t}=\sum_{i=0}^{t} r_{t-i}^{p>i} S_{t-i}
$$

(A continuous time version of this equation can be constructed using integrals.) Incorporating this correctly into the model is nontrivial. In addition, the data needed to calculate the terms in this formula are only available for the most recent time periods. Our model is an approximation that assumes the distribution of prison terms is stationary. If the distribution of prison terms is stationary, then $r^{p}$ will be equal to the reciprocal of the mean length of prison term. 
the crime rate, $r^{c}$, nor the imprisonment rate given sentencing, $r^{p}$, by race for the entire time period. Therefore, we drop $\ln r^{c}$ from the model and measure the arrest rate, $r^{a}$, as the rate of arrest among the population (rather than among those who have committed crimes). This means that changes in "arrest" in the results presented below incorporate both changes in criminal behavior and changes in the law enforcement response to that behavior. We also drop $\ln r^{p}$ from the model, assuming that $r^{p}=1$, per our discussion in footnote 5 . This means that the sentencing component captures only sentencing to prison and not all determinations of guilt (convictions). The final model is thus:

$$
\ln X+\ln r^{a}+\ln r^{s}=\ln P
$$

or equivalently:

$$
X r^{a} r^{s}=P
$$

In words, the number of people in the population times the population arrest rate times the rate at which people arrested are sentenced to prison equals the number of people in prison.

National data on population and federal and state prison inmates by race come from published Census Bureau sources for each census year. Data on prison admissions by race come from the Bureau of Justice Statistics [7], and data on arrests by race from the FBI's Uniform Crime Reports. We include arrests for Part I Index Crimes (murder, non-negligent manslaughter, rape, robbery, aggravated assault, burglary, larceny, auto theft, and arson) plus drug crimes. The raw data and intermediate calculations on which the analysis below is based are provided in Appendix A, Tables A1 and A2.

The UCR data are imperfect in three ways. First, not all police agencies report arrests to the FBI. We inflate arrest counts using data on the proportion of the total U.S. population living in reporting areas in the applicable year. We are unable to calculate separate inflation factors by race. Second, in 1940 and 1950, arrests by race are based on fingerprint cards submitted to the FBI and therefore likely understate the total number of arrests. Since we focus on the most serious crimes, the degree of understatement may be small. These problems will affect our main results only if they vary significantly by race. The standard solution to underreporting in UCR data (using only homicides, which are least subject to underreporting) is not appropriate here, since we are working with all Part I index crimes and rates of arrests and sentences to prison are likely to be different for homicides as compared to all Part I crimes. Third, arrests are only reported to the FBI when three conditions are met: when at least one person is arrested, charged, and prosecuted for an offense. This means that arrests leading to dropped charges or dismissals are not recorded in the data, understating arrests. This will be a problem if rates of dropped charges or dismissals vary by race and/or time, but the degree to which this is the case is unclear. See Lynch and Addington [71] for a more detailed discussion of the weaknesses of the UCR data.

\subsection{Part II: Decomposing State-Level Variation in Incarceration Rates}

To further understand the sources of changes in the RDI, we use state-level data from the 1940 through 1980 censuses to model variation in prison populations by race using Poisson regression [72]. In Poisson regression, one moves between counts and rates by including the log of the number of individuals at risk (the exposure) as an independent variable in the rate equation with its coefficient constrained to one (so called "normalization"). Specifically, we model the incarceration rate of the population:

$$
P / X=f(Z b)
$$


where $Z$ is a vector of characteristics for an area, $b$ is a vector of parameters to be estimated measuring the relation between each characteristic, and $\mathrm{f}$ is some function. Since $P / X$ is a rate, it is natural to assume that it is linear in the logs, that is ${ }^{5}$ :

$$
\ln P=\ln X+Z b
$$

Our unit of analysis in this model is the race by state combination in each census year 1940-1980. We use data from the 39 states that contained the vast majority of the black population between 1940 and 1980. Excluded states include Alaska, Hawaii, Maine, Montana, New Hampshire, North Dakota, South Dakota, Utah, Vermont, and Wyoming. In these states, published census reports of number of inmates are not broken down by race in many of the years in our data, and because there are so few blacks in these states, estimates of state level variables for blacks from sample microdata (used in Part III below) have substantial measurement error or are impossible to calculate. We also exclude Washington, D.C. because of incomplete political data and its hybrid local/federal justice system. Excluding these states and D.C. leads to the loss of between one and two percent of the black population and between one and 2.5 percent of black inmates across all years. Because our analyses weight using the state population for each race, the dropped observations if included would have little effect on our estimates. Weighting by the state population for each race also ensures that the decomposition reflects national-level changes in the RDI and corresponds to the national accounting model in Part I.

Our goal in this analysis is to decompose changes over time in the racial difference in incarceration into components associated with demographic processes related to migration and population growth at the state level. We begin in this section with a simple Poisson regression model of the number of inmates $(I)$ by state $(s)$ by time $(t)$ by race $(b)$ :

$$
\ln \left(I_{s t b}\right)=\ln \left(P o p_{s t b}\right)+a+b_{1} B+b_{2} T+b_{3} S+b_{4}(B \times T)+b_{5}(S \times B)+b_{6}(S \times T)+e
$$

where:

$I_{s t b}=$ number of inmates in state $\mathrm{s}$ at time $\mathrm{t}$ of race $\mathrm{b}$

$P_{o p} p_{s b}=$ population in state $\mathrm{s}$ at time $\mathrm{t}$ of race $\mathrm{b}$

$B=$ black dummy (1 for blacks, 0 for whites)

$T=$ set of time dummies

$S=$ set of state dummies

$B \times T=$ set of race by time interaction dummies

$S \times B=$ set of state by race interaction dummies

$S \times T=$ set of state by time interaction dummies

This model is almost fully saturated, and we can think of the error term as representing the missing $B \times T \times S$ interaction. Note that $\ln \left(P o p_{s t b}\right)$ is the "exposure" in Poisson regression and its coefficient is constrained to 1 .

We use estimates from this model in conjunction with state by race population weighted means for the variables to decompose trends over time in white incarceration and black incarceration. We then subtract these race-specific decompositions to reveal the components of the racial difference in incarceration over the time period. The procedure is as follows:

(1) Estimate the model to generate the coefficients $a$ and $b_{1}$ through $b_{6}$.

(2) Calculate population-weighted means for each variable in each year for each race.

5 This amounts to examining changing in $\ln X$ and $\ln r^{\text {casp }}$ in the accounting model in Part I (Section 3.1). 
(3) For each race and year combination, calculate the components of the overall predicted value from the model using the estimated coefficients from step 1 and the means from step 2 . The contribution of the various components will be a function of both their changes over time (captured by the means) and their impact on incarceration (captured by the coefficients).

(4) Separately by race, subtract the components across years to decompose trends in white incarceration over time and black incarceration over time. Here we compare adjacent census years with one another and, in order to examine the entire period, compare 1940 to 1980.

(5) Subtract the components of the black trends from the components of the white trends in order to decompose changes in RDI into its component parts.

The weighting of the means in Step 2 is critical because it allows differences in the population distribution across races, states, and years to influence the total contribution of the components derived from the dummy variables and interactions. Note that this procedure is similar to a Blinder-Oaxaca decomposition [73,74], which decomposes differences between groups or time periods into differences due to differences in mean characteristics (so called "endowments") and differences in effects of those characteristics by group (coefficients). The most well-known applications of the Blinder-Oaxaca decomposition are to labor market discrimination by race and gender, in which differences in mean wages by race or gender are decomposed into differences in group characteristics (e.g., education, work experience) and differences in "returns" to those characteristics, with differences in returns being interpreted as evidence of discrimination. The decomposition here is more complex because it involves both race and time (for multiple time periods), but the intuition is similar. We are decomposing the racial and temporal differences in means in incarceration into components due to the changing characteristics of each group at each time point (here the size of each group and where members of each group live) and the effects of those characteristics (differences in incarceration rates by race in different states).

Each term on the right side in the equation makes a different type of contribution to the decomposition. We explain this in detail to ensure that the reader will understand the results reported below.

$\ln \left(P o p_{s t b}\right) \quad$ Captures changes in the relative size of black as opposed to white population.

a Does not appear in decomposition (constant is subtracted out).

$b_{1} B \quad$ Does not appear in decomposition (common race effect over time is subtracted out).

$b_{2} T \quad$ Does not appear in decomposition (common time effects across race are subtracted out).

$b_{3} S \quad$ Captures the influence of population increases (presumably through migration) in states with higher incarceration rates.

$b_{4}(B \times T) \quad$ Captures the remaining trends in the racial difference in incarceration, which we seek to explain in this study.

$b_{5}(S \times B) \quad$ Captures the influence of black population increases in states that disproportionately incarcerate blacks.

$b_{6}(S \times T) \quad$ Captures the influence of population change in states with changing incarceration rates over time.

\subsection{Part III: Modeling Incarceration Rates Using State Characteristics}

Finally, we model state-by-race-by-time-specific incarceration levels-our basic dependent variable-using state-level characteristics that measure the processes suggested by the theories outlined above. The goal is to provide specific tests of hypotheses about predictors of black and white incarceration rates and to examine the extent to which these predictors can account for the change in the RDI. These analyses also provide an additional test of the role of demographic processes such as migration and the accompanying urbanization and segregation that occurred throughout the period of interest by measuring those processes directly.

Table 1 describes the measurement of our state characteristic variables that operationalize these theories. Most state characteristics come from published census bureau reports and from census microdata aggregated to the state level by race and year [75]. Political data were generated from 
ICPSR's Candidate Name and Constituency Totals dataset [76]. Segregation measures come from data assembled by Jacob Vigdor [77].

Table 1. State characteristic variables.

\begin{tabular}{|c|c|}
\hline Variable & Description \\
\hline Inmates & Population of Federal, State, and Local Prisons and Jails \\
\hline Pop & State Population \\
\hline \multicolumn{2}{|r|}{ Demographic and Economic Characteristics } \\
\hline Wage Income 25 th \%tile & $\begin{array}{l}\text { 25th Percentile of Distribution of Annual Income from Wages, Employed } \\
\text { Males Age } 16 \text { and over, } 1990 \text { dollars (thousands) }\end{array}$ \\
\hline$\%$ Single Mothers & $\%$ of Mothers with Children under 18 who are unmarried \\
\hline Unemployment Rate & Unemployment Rate for males age $\geqslant 16$ \\
\hline$\%$ High School Grad & $\%$ of Persons $\geqslant 18$ Graduated from High School \\
\hline$\%$ age $16-29$ & $\%$ of population Age 16 to 29 \\
\hline Wage Inter-quartile Range & $\begin{array}{l}\text { Interquartile Range of Annual Income from Wages, Employed Males Age } 16 \\
\text { and over, } 1990 \text { dollars (thousands) }\end{array}$ \\
\hline \multicolumn{2}{|r|}{ Population Growth, Migration, and Urbanization } \\
\hline$\%$ Black & $\%$ of Population that is black* \\
\hline Black Pop Change & $\%$ Change in Black Population Since previous Census * \\
\hline$\%$ Born Other Region & $\%$ of Population Born in Another Region \\
\hline$\%$ Urban & $\%$ of Population Living in Metropolitan Areas \\
\hline \% Agricultural Empl. & $\%$ of Male Employed Workers Age 16 and over in Agricultural Occupations \\
\hline \% Manufacturing Empl. & $\%$ of Male Employed Workers Age 16 and over in Manufacturing Industries \\
\hline \multicolumn{2}{|r|}{ Political Context (source: ICPSR [76]) } \\
\hline Republican Gov. & Indicator for Sitting Governor is Republican * \\
\hline$\%$ Republican Votes & $\%$ of Votes for Republican Candidate in most recent Presidential Election * \\
\hline \multicolumn{2}{|r|}{ Segregation (source: Cutler, Glaeser, and Vigdor [77]) } \\
\hline Dissimilarity Index & $\begin{array}{l}\text { Dissimilarity Index for Metro Areas or cities, state mean weighted by } \\
\text { metro/city black population }(0-100) *\end{array}$ \\
\hline Dissimilarity Imputed & Indicator for missing dissimilarity index imputed * \\
\hline
\end{tabular}

Note: * State values not race specific. Source: Decennial Census [75] unless otherwise noted.

We operationalize general economic wellbeing among those most likely to be incarcerated as wage income at the 25 th percentile of the wage income distribution of employed males 16 years and older (in thousands of 1990 dollars). Female-headed families are measured by the proportion of mothers with children under 18 without a husband present in the household. Unemployment is measured as the unemployment rate for males 16 years and older. Education levels are operationalized as the proportion of people 18 years old and over who have graduated from high school. Changes in the age structure of the population are operationalized as the percentage of all individuals who are between the ages of 16 and 29, the age group most likely to be incarcerated. Within-race income inequality is measured as the inter-quartile range of wage income among employed males age 16 and over (in thousands of 1990 dollars).

Racial population change is measured by the percentage of the total state population that is black and the percentage change in the black population. Migration is captured by the proportion of the population that was born in a different census region than the state [13]. Urbanization is operationalized as the proportion living in metro areas. Closely connected to urbanization and migration is the shift away from farm work, which is measured by the proportion of male workers in agricultural occupations, and the rise of manufacturing employment, captured by the proportion of male workers in manufacturing industries.

Political context is measured using an indicator of whether the current governor is a Republican and using the proportion of votes going to the Republican candidate in the most recent presidential election. 
Normally residential segregation by race is measured at the level of the city or metropolitan area rather than the state. To construct state-level measures, we take the mean of the segregation measures for all of the cities or metropolitan areas in the state, weighted by the black population of each city/metropolitan area. As our measure of segregation, we use the dissimilarity index. This measure, a widely used segregation measure, can be understood as the proportion of the black population that would have to move neighborhoods (either census tracts or city wards, depending on the year) in order to make all of the neighborhoods have the same proportion black as the proportion black in the city /metropolitan area overall (see Cutler, Glaeser, and Vigdor [77] for more information on the segregation data). Some states in some years have no cities or metropolitan areas with segregation measures, particularly in 1950. For such observations, we impute a segregation value using multiple imputation by chained equations (Royston's "ice" command in Stata) predicting the missing value using segregation measures from other years as well as percentage urban, percentage black, and black population change for the current year and census region and division dummies. In the regression models, we also include a dummy variable for whether a segregation value was imputed. ${ }^{6}$

We use these variables to model the count of the number of inmates in each state-year-race combination, again using a Poisson model. Because some state characteristics operate differently for blacks and whites, we estimate models separately by race. The "exposure" is again the population size, and we weight both black and white regressions by the mean proportion of the total U.S. black population in the state between 1940 and 1980. This prevents up-weighting later years (when populations are larger) and ensures that both black and white regressions weight states equivalently. We include state fixed effects, which remove all race-specific time invariant differences in incarceration rates across states, focusing our analysis on within-state changes over time. Finally, we mean center all variables by subtracting the black mean. Thus the constant and year dummies capture the mean log incarceration rates with state characteristics held at the mean values experienced by the typical black resident. This allows for comparisons of the constant and dummies across black and white regressions and across models with different independent variables.

\section{Results}

\subsection{Part I: A National Accounting Model}

Figure 2 shows our decomposition of the national trends in the racial difference in incarceration. The dashed line with the diamonds shows the unadjusted difference between the log of the number of black prisoners and the $\log$ of the number of white prisoners $\left(\ln P_{b}-\ln P_{w}\right)$. In 1940, there are many more white prisoners than black prisoners, but by 1980 there are almost as many black prisoners as white prisoners. The thick solid line with squares shows the difference in the rate of incarceration by adjusting for population size $\left(\left[\ln P_{b}-\ln P o p_{b}\right]-\left[\ln P_{w}-\ln P o p_{w}\right]\right)$. Here the difference in incarceration rates is clearly evident, and we see the familiar increase over time in the racial difference in incarceration. The increase appears to be relatively steady throughout the time period, with a somewhat slower increase during the 1950s. The population-adjusted line increases less steeply than the unadjusted line, indicating that the growth in the black population relative to the white population explains some of the increase in RDI. Calculations indicate that adjusting for population accounts for $32 \%$ of the original

6 In developing this parsimonious set of state characteristics, we considered a large number of alternative measures. These included age-specific unemployment rates, full- and part-time employment rates, percentage college graduates and percentage middle school graduates, median age and more specific population age categories, weekly rather than annual wages, the black/white population ratio, percentage born in another census division, percent of the population living in cities of various population sizes, employment in the agricultural industry rather than agricultural occupations, percent of votes for the Republican gubernatorial candidate, dissimilarity index weighted by total city/metro population, and the isolation index. These measures are all highly correlated with variables included in the analysis and results are not sensitive to alternative measures. 
trend between 1940 and 1980. During this period the white population grew by 59\% whereas the black population grew by $106 \%$, nearly twice as fast. ${ }^{7}$

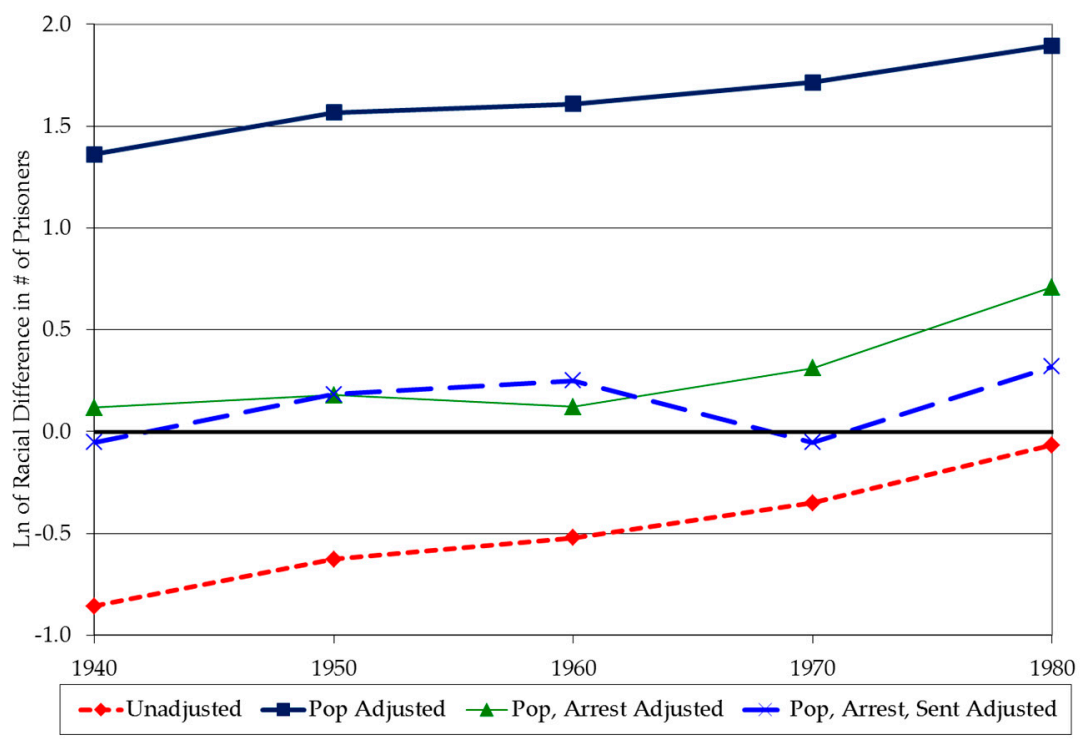

Figure 2. Racial differences in prisoners, adjusted for different factors.

The thin solid line with triangles further adjusts for the arrest rates in the black and white populations (recall that this population arrest rate includes both the crime rate and the rate of arrest among those who have committed a crime). Between 1940 and 1960, adjusting for racial differences in arrest rates explains virtually all of race difference in incarceration; only one percent of the 1940 to 1960 trend remains unexplained after adjusting for arrest rates. After 1960, racial differences in arrest rates explain much of the racial difference in incarceration, though a declining amount; the solid line with triangles slowly diverges from the flat solid line representing equality. After 1960, however, there were actually larger increases in arrest rates among whites than among blacks. Arrest rates increased $177 \%$ among whites and 105\% among blacks over this period. As such, changes in the racial differential in arrest rates during the 1960s and 1970s cannot explain the increasing racial difference in incarceration during that period, and adjusting for arrest rates results in a larger racial difference in incarceration in 1980 compared to $1960 .^{8}$

By definition, the remaining differences are accounted for by differences in rates of sentencing to prison (or prison term length) among those arrested. In subsequent sections we examine why these rates have changed. In both the 1960s and 1970s, the rate of sentencing for blacks appears to have increased relative to that for whites. The dashed line with the $x^{\prime}$ s adjusts for population, arrests, and for the likelihood of being sentenced to prison. This line hovers around the zero line, with the black and white values being essentially equal in 1940 and 1970. We suspect that the remaining differences in 1950, 1960, and 1980 reflect imperfections in our data. Sentencing appears to add little to the explanation of racial differences in incarceration between 1940 and 1960 . However, between 1960 and 1980, sentencing differences account for a considerable portion of the racial difference in incarceration.

7 Rates of institutionalization of the mentally ill have been proposed as a predictor of incarceration rates after 1970 [78]. Results presented here are not sensitive to removing from the population at risk of incarceration individuals institutionalized in facilities for the mentally ill or mentally handicapped, nor is the size of the population in mental hospitals a significant predictor of incarceration in prison in the regression models in Part III below. Raphael and Stoll [79] find that the de-institutionalization of the mentally ill did not contribute to increasing incarceration rates prior to 1980.

8 Focusing on contact crimes only, LaFree, $\mathrm{O}^{\prime}$ Brien, and Baumer [69] report increases in the ratio of black to white arrest rates for homicide, robbery, and rape during the 1960s and decreases in the 1970s. They also find decreases in the black-white ratio for aggravated assaults in both the 1960s and 1970s. 
In summary, this part of analysis suggests the following conclusions. First, slightly less than one-third of the increase in the racial difference in incarceration during the 1940-1980 period was due to black population increase. This contribution occurs largely uniformly throughout the period. Second, differential arrest rates explain the vast majority of the racial difference in incarceration in 1940, 1950, and 1960, and differential changes in arrest rates account for the increase during that period not attributable to differential population growth. During the 1960s and 1970s, larger increases in arrest rates among whites than blacks imply that arrests cannot account for the increase in the racial differences in incarceration over that period. Instead, the remaining two-thirds of the increase in the racial difference in incarceration from 1960 to 1980 is due to racial differences in sentencing rates or sentencing length. These differences in sentencing could reflect a number of factors, including discrimination, racial differences in types of offense, or racial differences in individuals' accumulated criminal records.

\subsection{Part II: Decomposing State-Level Variation in Incarceration Rates}

Model 1 in Table 2 shows the basic trend to be decomposed. It predicts inmates using only time dummies, the black dummy, and the black by time dummies, and can be thought of as a simple display of the mean of the log of the number of inmates for blacks and whites over time. ${ }^{9}$ The first column displays results representing the constant and the time trend with 1940 as the base year and is the time trend for whites. The third column displays the results from the black dummy and black by time interaction terms, the focus of our analysis. The trend in the racial difference in incarceration is clearly evident. As expected, the racial difference in the log of the number of individuals incarcerated is increasing over time ( -0.736 for 1940 to 0.015 for 1980). The second column shows the implied coefficients for blacks, calculating by summing the first and third columns.

Table 2. Poisson regression models of inmates.

\begin{tabular}{ccccccc}
\hline & \multicolumn{3}{c}{ 1-Baseline Model } & \multicolumn{2}{c}{ 2-Residualized Time Trends } \\
\hline & Whites & Blacks & Blacks-Whites & Whites & Blacks & Blacks-Whites \\
\hline Constant & 9.162 & 8.426 & -0.736 & -6.421 & -4.558 & 1.863 \\
1950 & -0.237 & -0.127 & 0.110 & -0.382 & -0.191 & 0.190 \\
1960 & 0.009 & 0.288 & 0.279 & -0.426 & -0.129 & 0.297 \\
1970 & -0.069 & 0.326 & 0.394 & -0.848 & -0.553 & 0.295 \\
1980 & -0.010 & 0.741 & 0.751 & -0.772 & -0.374 & 0.398 \\
N & \multicolumn{3}{c}{390} & & $-2.75 \times 10^{10}$ \\
Log Likelihood & \multicolumn{7}{c}{$-2.21 \times 10^{12}$} & & \\
\hline
\end{tabular}

Notes: Model 2 also includes State Dummies, State $\times$ Black Dummies, State $\times$ Time Dummies, and $\ln ($ pop) term (with coefficient constrained to 1); Both models weighted by Pop.

9 Because we have population rather than sample data and therefore there is no sampling error, we are not concerned with standard errors in this analysis. 
Model 2 in Table 2 shows analogous estimates from the full model described above. Coefficients for the individual state, state by time, and race by time dummies are omitted for space reasons. Comparing the rightmost columns for each of the two models shows that accounting for population increase and for migration has greatly reduced the time trend in the racial difference in incarceration, particularly after 1960. Whereas the difference between 1980 and 1940 in the RDI in model 1 is 0.751 , it drops to 0.398 in model 2.

Table 3 shows the decomposition of white trends by decade and, in the rightmost column, for the entire period 1940 to 1980. For each time period, the total trend is decomposed into components contributing to an increase in incarceration over time and those contributing to a decrease over time, with components contributing to the decrease indicated by shaded cells. For each period, the raw values in the difference in $\ln$ (inmates) metric are to the left, and percentages of the total increase or decrease are on the right. The three total rows near the bottom of the table show that during the 1940s and 1960s, components leading to a decrease in incarceration among whites were larger than those leading to an increase, resulting in an overall decrease during those two decades and a slight overall decrease over the entire period, 1940-1980. The magnitudes of the overall increases in incarceration among whites during the 1950s and 1970s were about the same.

Increasing population pushes white incarceration numbers higher in all decades, but had an especially large impact in the 1940s and 1950s, a moderate impact in the 1960s, and contributed to over half of the 1940 to 1980 increase in white incarceration. As captured by the state dummies, population increases in states with higher incarceration rates, most likely due to migration rather than differential birth rates, also consistently increase white incarceration over time, contributing to about 13 percent of the overall increase from 1940 to 1980. Finally, as captured by the state by time dummies, population change in states with changing incarceration rates has differing impacts in each decade. For example, an increase in the population of a state with increasing incarceration rates would, ceteris paribus, lead to an increase in incarceration. Similarly, a decrease in the population of a state with decreasing incarceration rates would also lead to an increase in incarceration. This component leads to a very slight decline in white incarceration in the 1940s and to increases in the 1950s, 1960s, and 1970s. Throughout the entire period, the net impact of a decrease in the population in states with decreasing incarceration rates is positive and accounts for about 32 percent of the overall increase in white incarceration. The time dummies capture the overall time trend for each period not accounted for by the other components. Their relatively large magnitudes, especially in the individual decades, suggest that adding other variables to the model is necessary to fully understand the time trend in white incarceration.

Table 4 performs the same decomposition for black incarceration. The bottom section of the table shows a similar temporal story for black incarceration as for white incarceration, except that the net declines in incarceration in the 1940s and 1960s are smaller for blacks, and the net increases in the 1950s and 1970s are larger for blacks. This leads to an overall increase in black incarceration between 1940 and 1980. Slightly over half of this increase occurred during the 1970s, with the remainder occurring in the 1950s.

As among whites, national population increase plays an important role in the increase in incarceration among blacks in all time periods. In these data, for blacks, it accounts for a little over a third of the overall increase between 1940 and 1980. As captured by the state dummies, population change in states with different incarceration rates pushed black incarceration rates down between 1940 and 1970 and pushed them up in the 1970s, presumably as blacks moved to lower-incarceration states in the first period and higher incarceration states in the second. However, the magnitudes of these effects are relatively small. As captured by the black by state dummies, black population growth in states with higher black incarceration rates increased black incarceration in all decades but the 1970s, having its biggest impact in the 1940s, 1950s, and 1960s. This component contributes about 13 percent of the overall increase in black incarceration from 1940 to 1980. Finally, state by time dummies capture the changes in black incarceration due to changes in population in states with changing incarceration 
rates. These changes pushed black incarceration upward throughout the period, as blacks moved to states whose incarceration rates were increasing and away from states where they were decreasing. Between 1940 and 1980, these movements on net contributed to about 30 percent of the increase in black incarceration. Again, the relatively large contributions of the time dummies and black by time dummies in many periods suggest that additional variables are necessary to understand black incarceration trends. Understanding why incarceration rates increased in states where blacks moved also requires examining additional variables, as we do in Part III.

Table 5 differences the components of the black and white trends in order to decompose the time trend in the racial difference in incarceration. The bottom section of the table indicates that the racial difference in incarceration increased in all years, though not evenly. The 1950s account for almost one-third of the change, and the 1970s account for over one-third. As indicated by the $\ln$ (Pop) row, differential national population increase pushed up the racial difference in incarceration in all decades except the 1940s and accounted for about one-fifth of the overall increase between 1940 and $1980 .{ }^{10}$ Differential population change in states with higher overall incarceration rates lowers the racial difference in all years, though its effects are largest in the 1940s and 1950s and moderate in the 1960s. Black population increase in states where black incarceration rates are disproportionately higher than those of whites increases the differential in all periods except the 1970s, contributing to about 22 percent of the overall increase in the racial differential between 1940 and 1980. In other words, the white population increased faster in states with overall higher incarceration rates throughout the period, lowering the RDI, but black population increase in states with higher black incarceration rates throughout the period increased the RDI. Finally, differential movement to states with increasing incarceration rates over time also contributes about one-fifth of the overall increase between 1940 and 1980, leading to an increase in all periods and having its biggest impact in the 1940s and 1950s. In other words, the black population increases more in states whose incarceration rates were rising, increasing the RDI.

10 The accounting exercise in Part I finds that differential population change accounted for about one-third of RDI. We suspect this difference is due to the differing coverage of the two analyses. The analysis in Part I uses national data, whereas this analysis uses state-level data for 39 states. Because the black population in the excluded states is negligible, the main difference is the excluded white population. 
Table 3. Decomposition of White Trends in Incarceration, By Period.

\begin{tabular}{|c|c|c|c|c|c|c|c|c|c|c|}
\hline \multirow[b]{2}{*}{ Pop Change $[\ln ($ pop)] } & \multicolumn{2}{|c|}{ 1940-1950 } & \multicolumn{2}{|c|}{ 1950-1960 } & \multicolumn{2}{|c|}{ 1960-1970 } & \multicolumn{2}{|c|}{ 1970-1980 } & \multicolumn{2}{|c|}{ 1940-1980 } \\
\hline & 0.126 & $(81.9 \%)$ & 0.168 & $(70.8 \%)$ & 0.103 & $(37.6 \%)$ & 0.015 & $(8.7 \%)$ & 0.411 & $(54.9 \%)$ \\
\hline White Time Trend [Time Dummies] & -0.401 & $(98.1 \%)$ & -0.065 & $(100.0 \%)$ & -0.401 & $(100.0 \%)$ & 0.075 & $(45.2 \%)$ & -0.792 & $(100.0 \%$ \\
\hline Pop Increase in States With High Incarceration Rate [State Dummies] & 0.028 & $(18.1 \%)$ & 0.028 & $(11.7 \%)$ & 0.020 & $(7.3 \%)$ & 0.025 & $(14.8 \%)$ & 0.100 & $(13.3 \%)$ \\
\hline Racial Difference in Incarceration Trend [Black X Time Dummies] & - & & - & & - & & - & & - & \\
\hline $\begin{array}{l}\text { Black Pop Change in States Disproportionately Incarcerating Blacks } \\
\text { [Black X State Dummies] }\end{array}$ & - & & - & & - & & - & & - & \\
\hline Pop Change in States With Changing Incarceration Rate [State X Time Dummies] & -0.008 & $(1.9 \%)$ & 0.041 & $(17.5 \%)$ & 0.152 & $(55.2 \%)$ & 0.052 & $(31.3 \%)$ & 0.238 & $(31.7 \%)$ \\
\hline Increase Total & 0.154 & & 0.237 & & 0.275 & & 0.167 & & 0.749 & \\
\hline Decrease Total & -0.408 & & -0.065 & & -0.401 & & -- & & -0.792 & \\
\hline GRAND TOTAL & -0.255 & & 0.172 & & -0.126 & & 0.167 & & -0.043 & \\
\hline Raw Trend & -0.253 & & 0.174 & & -0.130 & & 0.174 & & -0.037 & \\
\hline Unexplained Trend (Grand Total - Raw Trend) & 0.002 & & 0.002 & & -0.004 & & 0.007 & & 0.006 & \\
\hline
\end{tabular}

Notes: Shaded cells highlight decreases; percentages show proportion of total increase (or decrease) accounted for by component for period.

Table 4. Decomposition of Black Trends in Incarceration, by Period.

\begin{tabular}{|c|c|c|c|c|c|c|c|c|c|c|}
\hline \multirow[b]{2}{*}{ Pop Change [ln(pop)] } & \multicolumn{2}{|c|}{ 1940-1950 } & \multicolumn{2}{|c|}{ 1950-1960 } & \multicolumn{2}{|c|}{ 1960-1970 } & \multicolumn{2}{|c|}{ 1970-1980 } & \multicolumn{2}{|c|}{ 1940-1980 } \\
\hline & 0.071 & $(25.7 \%)$ & 0.186 & $(38.9 \%)$ & 0.180 & $(44.1 \%)$ & 0.150 & $(33.4 \%)$ & 0.587 & $(38.8 \%)$ \\
\hline White Time Trend [Time Dummies] & -0.401 & $(96.3 \%)$ & -0.065 & $(80.6 \%)$ & -0.401 & $(96.9 \%)$ & 0.075 & $(16.7 \%)$ & -0.792 & $(96.7 \%)$ \\
\hline Pop Increase in States With High Incarceration Rate [State Dummies] & -0.016 & $(3.7 \%)$ & -0.016 & $(19.4 \%)$ & -0.013 & $(3.1 \%)$ & 0.017 & $(3.8 \%)$ & -0.027 & $(3.3 \%)$ \\
\hline Racial Difference in Incarceration Trend [Black X Time Dummies] & 0.076 & $(27.6 \%)$ & 0.091 & $(19.0 \%)$ & 0.012 & $(3.0 \%)$ & 0.104 & $(23.0 \%)$ & 0.283 & $(18.7 \%)$ \\
\hline $\begin{array}{l}\text { Black Pop Change in States Disproportionately Incarcerating Blacks } \\
\text { [Black X State Dummies] }\end{array}$ & 0.072 & $(26.0 \%)$ & 0.067 & $(14.1 \%)$ & 0.058 & $(14.3 \%)$ & -0.005 & $(100.0 \%)$ & 0.192 & $(12.7 \%)$ \\
\hline Pop Change in States With Changing Incarceration Rate [State X Time Dummies] & 0.057 & $(20.7 \%)$ & 0.133 & $(28.0 \%)$ & 0.157 & $(38.5 \%)$ & 0.104 & $(23.0 \%)$ & 0.451 & $(29.8 \%)$ \\
\hline Increase Total & 0.276 & & 0.477 & & 0.407 & & 0.450 & & 1.513 & \\
\hline Decrease Total & -0.416 & & -0.081 & & -0.414 & & -0.005 & & -0.818 & \\
\hline Grand Total & -0.140 & & 0.397 & & -0.007 & & 0.445 & & 0.695 & \\
\hline Raw Trend & -0.151 & & 0.371 & & 0.035 & & 0.418 & & 0.673 & \\
\hline Unexplained Trend (Grand Total - Raw Trend) & 0.010 & & 0.026 & & -0.042 & & 0.027 & & 0.022 & \\
\hline
\end{tabular}

Notes: Shaded cells highlight decreases; percentages show proportion of total increase (or decrease) accounted for by component for period. 
Table 5. Decomposition of Black-White Differences in Incarceration, By Period.

\begin{tabular}{|c|c|c|c|c|c|c|c|c|c|c|}
\hline \multirow[b]{2}{*}{ Pop Change [ln(pop)] } & \multicolumn{2}{|c|}{ 1940-1950 } & \multicolumn{2}{|c|}{ 1950-1960 } & \multicolumn{2}{|c|}{ 1960-1970 } & \multicolumn{2}{|c|}{ 1970-1980 } & \multicolumn{2}{|c|}{ 1940-1980 } \\
\hline & -0.055 & $(55.9 \%)$ & 0.018 & $(6.8 \%)$ & 0.076 & $(50.3 \%)$ & 0.136 & $(46.7 \%)$ & 0.176 & $(20.4 \%)$ \\
\hline White Time Trend [Time Dummies] & - & & - & & - & & - & & - & \\
\hline Pop Increase in States With High Incarceration Rate [State Dummies] & -0.043 & $(44.1 \%)$ & -0.043 & $(100 \%)$ & -0.033 & $(100 \%)$ & -0.007 & $(57.9 \%)$ & -0.127 & $(100 \%)$ \\
\hline Racial Difference in Incarceration Trend [Black X Time Dummies] & 0.076 & $(35.9 \%)$ & 0.091 & $(33.8 \%)$ & 0.012 & $(8.0 \%)$ & 0.104 & $(35.6 \%)$ & 0.283 & $(32.7 \%)$ \\
\hline $\begin{array}{l}\text { Black Pop Change in States Disproportionately Incarcerating Blacks } \\
\text { [Black X State Dummies] }\end{array}$ & 0.072 & $(33.7 \%)$ & 0.067 & $(25.1 \%)$ & 0.058 & $(38.3 \%)$ & -0.005 & $(42.1 \%)$ & 0.192 & $(22.2 \%)$ \\
\hline Pop Change in States With Changing Incarceration Rate [State X Time Dummies] & 0.065 & $(30.4 \%)$ & 0.092 & $(34.3 \%)$ & 0.005 & $(3.4 \%)$ & 0.051 & $(17.7 \%)$ & 0.213 & $(24.7 \%)$ \\
\hline Increase Total & 0.213 & & 0.268 & & 0.152 & & 0.291 & & 0.864 & \\
\hline Decrease Total & -0.098 & & -0.043 & & -0.033 & & -0.013 & & -0.127 & \\
\hline $\begin{array}{l}\text { Grand Total } \\
\text { (Row Percent) }\end{array}$ & $\begin{array}{l}0.115 \\
(15.6 \%)\end{array}$ & & $\begin{array}{l}0.225 \\
(30.5 \%)\end{array}$ & & $\begin{array}{l}0.119 \\
(16.2 \%)\end{array}$ & & $\begin{array}{l}0.278 \\
(37.7 \%)\end{array}$ & & $\begin{array}{l}0.737 \\
(100.0 \%)\end{array}$ & \\
\hline Raw Trend & 0.103 & & 0.197 & & 0.165 & & 0.244 & & 0.709 & \\
\hline Unexplained Trend (Grand Total - Raw Trend) & 0.012 & & 0.028 & & -0.046 & & 0.035 & & 0.028 & \\
\hline
\end{tabular}

Notes: Shaded cells highlight decreases; percentages show proportion of total increase (or decrease) accounted for by component for period. 


\subsection{Part III: Modeling Incarceration Rates Using State Characteristics}

The two descriptive decomposition analyses above provide information on the proximate causes of changes in the RDI, but more detailed explanations of specific causes are needed to understand the patterns revealed. For example, how can we understand the role of black population increases in states with rising black incarceration rates? In addition, the remaining importance of the black by time dummies in the decomposition of the black-white incarceration differential, about one-third of the total between 1940 and 1990, still needs to be explained. As such, social processes in addition to the changing geographic location of whites and blacks by state should also be taken into account in understanding the trend.

We begin by examining how various state characteristics that are hypothesized above to affect incarceration rates changed over time between 1940 and 1980. State means by race and time, weighted by the proportion of the black population that resides in each state in each year, are provided in Appendix B, Table B1. Here we describe a number of trends in the state characteristics that are worthy of note. Some of these show improvement in the situation of blacks relative to that of whites and some of these show declines.

- $\quad$ The gap in wage income at the 25th percentile of the wage distribution became wider until 1970 and then began to close. ${ }^{11}$

- The proportion of single mothers increased among both blacks and whites but increased more among blacks.

- The racial gap in the unemployment rate held relatively steady through 1970 and then increased substantially by 1980 .

- Though education increased among blacks throughout the period, blacks lost ground relative to whites through 1970.

- The proportion of blacks and whites in the peak crime ages was fairly similar throughout the period.

- Wage inequality increased among both blacks and whites, and blacks had consistently lower within group inequality throughout the period.

We also note the following shifts related to population growth, migration, and urbanization, which are consistent with prior research [13]:

- The proportion of the state that was black where the typical black lived declined as the black population moved north and west.

- The likelihood of living in a state where black population change was high increased.

- The proportion of blacks born outside their current region of residence increased.

- Both blacks and whites urbanized, though blacks slightly more so than whites.

- Agricultural employment fell.

- Manufacturing employment increased, at least through 1970.

- Blacks and whites came to live in states that increasingly voted Republican and increasingly had Republican governors.

- Racial segregation increased slightly through 1970 and then declined somewhat during the 1970s.

We now turn to Poisson models similar to those above except that here we include only year dummies and add state characteristics. For each pair of regressions, we display the coefficients from the black and white models and the differences between the models in the constant and the year dummy coefficients. The differences in the year dummies can be interpreted as the remaining time

11 In interpreting these trends, it is important to keep in mind that states are weighted by their proportion of the total U.S. black population in the state in each year. As such, both the black and white means of any characteristic represent the state mean experienced by the typical black person in a particular census year. 
trend in the racial difference in the incarceration rate once the state characteristics included in the model are held constant at their black mean. The difference in the constant can be interpreted as the remaining racial difference in incarceration in the omitted year, 1940. Results are presented in Table $6 .{ }^{12}$ Rather than show one preferred model, we build up a series of models that progressively add explanatory variables. This procedure allows us to see how much more of the RDI can be explained by the added variables, providing information about their importance relative to other possible explanatory variables. Figure 3 shows the implied trends in the racial difference in log incarceration rates based on the models in Table 6.

The regressions in column (1) of Table 6 contain only the exposure, the constant, and the time dummies, which display the now-familiar racial difference in incarceration in 1940 that grows over time. The trend is displayed in Figure 3 with the thick solid line with the diamonds. Model (2) adds three demographic and economic characteristics, percentage single mothers, wage income at the 25th percentile, and the percentage of the population aged 16-29. Holding constant these characteristics increases the racial differential in 1940, as blacks were relatively disadvantaged compared to whites on these dimensions in that year (recall that since the independent variables are black-mean centered in both the white and black models, the white constant now reflects the mean incarceration rate for whites in 1940 were the mean characteristics of whites set to those of blacks). Entering these variables individually into the model suggests that controlling for the single parenthood variable is responsible for almost all of the increase in the 1940 racial gap in incarceration (models not shown). Holding constant these characteristics also accounts for almost all the trend in racial difference in incarceration in the 1940s, all of the trend in the 1950s, and a small fraction of the trend thereafter. The remaining trend in the racial difference in incarceration is displayed graphically in Figure 3 in the thick solid line with the circles.

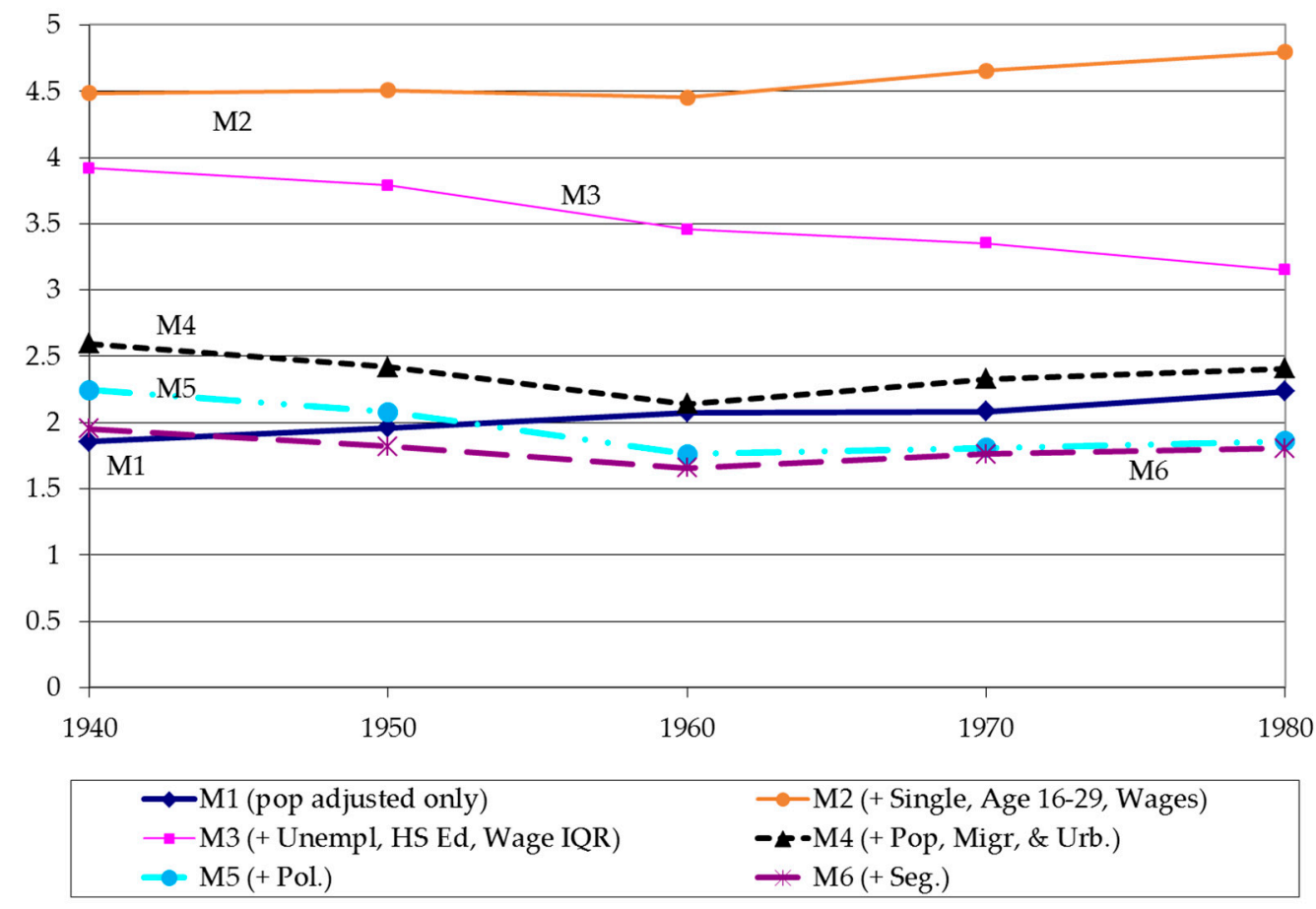

Figure 3. Remaining racial difference in $\ln ($ incarceration rate).

12 Table 6 does not display standard errors, $t$-tests, or $p$-values because the data are not from a sample and therefore there is no sampling error in the model estimates. 
Table 6. Poisson Regressions of Inmates with State Fixed Effects, by Race (weighted by \% of US black population in state in year).

\begin{tabular}{|c|c|c|c|c|c|c|c|c|c|c|c|c|c|c|c|c|c|c|}
\hline & \multicolumn{3}{|c|}{ (1) } & \multicolumn{3}{|c|}{ (2) } & \multicolumn{3}{|c|}{ (3) } & \multicolumn{3}{|c|}{ (4) } & \multicolumn{3}{|c|}{ (5) } & \multicolumn{3}{|c|}{ (6) } \\
\hline & Black & White & $B-W$ & Black & White & $B-W$ & Black & White & $B-W$ & Black & White & $B-W$ & Black & White & $B-W$ & Black & White & $B-W$ \\
\hline Constant & -4.73 & -6.59 & 1.85 & -4.96 & -9.44 & 4.48 & -4.85 & -8.76 & 3.92 & -4.43 & -7.02 & 2.59 & -4.43 & -6.68 & 2.25 & -5.49 & -7.44 & 1.95 \\
\hline 1950 & -0.24 & -0.35 & 0.11 & -0.14 & -0.16 & 0.02 & -0.16 & -0.03 & -0.13 & -0.78 & -0.60 & -0.18 & -0.77 & -0.60 & -0.17 & -0.78 & -0.65 & -0.13 \\
\hline 1960 & -0.09 & -0.31 & 0.22 & 0.28 & 0.31 & -0.03 & 0.14 & 0.60 & -0.46 & -1.04 & -0.59 & -0.46 & -1.02 & -0.54 & -0.49 & -0.90 & -0.60 & -0.29 \\
\hline 1970 & -0.32 & -0.55 & 0.23 & 0.34 & 0.17 & 0.17 & 0.14 & 0.71 & -0.56 & -1.54 & -1.27 & -0.27 & -1.48 & -1.05 & -0.44 & -1.28 & -1.09 & -0.19 \\
\hline 1980 & -0.07 & -0.45 & 0.38 & 0.81 & 0.49 & 0.31 & 0.46 & 1.23 & -0.77 & -1.45 & -1.26 & -0.19 & -1.36 & -0.97 & -0.39 & -1.12 & -0.97 & -0.15 \\
\hline \multicolumn{19}{|c|}{ Demographic and Economic Characteristics } \\
\hline Wage Income 25th \%tile & & & & -0.01 & -0.01 & & 0.02 & 0.00 & & 0.03 & 0.04 & & 0.03 & 0.03 & & 0.01 & 0.02 & \\
\hline$\%$ Single Parents & & & & -3.91 & -14.95 & & -4.96 & -11.92 & & -0.77 & -1.41 & & -0.81 & -0.17 & & -0.62 & -0.98 & \\
\hline$\%$ Age $16-29$ & & & & 2.86 & 8.57 & & 3.54 & 7.71 & & -2.95 & 5.49 & & -3.12 & 2.99 & & -1.97 & 2.60 & \\
\hline Unemployment Rate & & & & & & & 1.90 & 1.98 & & -0.19 & -1.18 & & -0.26 & -1.51 & & -0.31 & -1.52 & \\
\hline$\%$ High School Ed & & & & & & & -0.30 & -1.26 & & 0.43 & 0.64 & & 0.35 & 0.46 & & 0.28 & 0.51 & \\
\hline Wage Inter-quartile Range & & & & & & & 0.05 & -0.05 & & 0.07 & -0.02 & & 0.07 & -0.03 & & 0.05 & -0.02 & \\
\hline \multicolumn{19}{|c|}{ Population Growth, Migration, and Urbanization } \\
\hline$\%$ Black & & & & & & & & & & 0.30 & -2.26 & & 0.50 & -1.77 & & 1.37 & -1.65 & \\
\hline Black Pop Change & & & & & & & & & & 0.07 & -0.04 & & 0.06 & -0.09 & & 0.10 & -0.06 & \\
\hline \% Born Other Region & & & & & & & & & & 0.80 & 0.41 & & 0.82 & 0.51 & & 0.68 & 0.27 & \\
\hline$\%$ Urban & & & & & & & & & & 0.49 & 0.51 & & 0.50 & 0.39 & & 0.64 & 0.47 & \\
\hline$\%$ Agricultural Employment & & & & & & & & & & -0.75 & -1.03 & & -0.73 & -1.12 & & -0.73 & -0.91 & \\
\hline \% Manufacturing Employment & & & & & & & & & & 0.88 & -0.07 & & 0.89 & -0.44 & & 1.18 & -0.13 & \\
\hline \multicolumn{19}{|l|}{ Political Context } \\
\hline Republican Governor & & & & & & & & & & & & & 0.01 & 0.09 & & 0.02 & 0.09 & \\
\hline$\%$ Republican Votes & & & & & & & & & & & & & 0.05 & 0.15 & & 0.24 & 0.19 & \\
\hline \multicolumn{19}{|l|}{ Segregation } \\
\hline Dissimilarity Index & & & & & & & & & & & & & & & & 1.36 & 0.71 & \\
\hline Dissimilarity Imputed & & & & & & & & & & & & & & & & 0.12 & -0.02 & \\
\hline $\mathrm{N}$ & 194 & 195 & & 194 & 195 & & 194 & 195 & & 194 & 195 & & 194 & 195 & & 194 & 195 & \\
\hline Log Likelihood & -449.03 & -514.26 & & -384.80 & -381.05 & & -342.57 & -356.07 & & -211.90 & -264.92 & & -211.53 & -247.97 & & -181.29 & -238.05 & \\
\hline AIC & 906.06 & 1036.51 & & 783.60 & 776.10 & & 705.15 & 732.15 & & 455.80 & 561.85 & & 459.05 & 531.94 & & 402.57 & 516.09 & \\
\hline BIC & 919.15 & 1049.60 & & 806.47 & 799.01 & & 737.83 & 764.88 & & 508.09 & 614.22 & & 517.88 & 590.85 & & 467.93 & 581.55 & \\
\hline
\end{tabular}

Notes: Exposure = Population Size, All variables black-mean centered; Black regressions exclude Nevada in 1940 due to insufficient black population to generate state characteristics. 
Model 3 adds three additional demographic and economic characteristics: unemployment, education, and wage inequality. Holding constant these characteristics explains some of the racial difference in 1940, but more importantly also shifts the trend from an increasing racial difference over time to a decreasing one, reflecting the fact that over time blacks' status relative to that of whites' fell on these demographic and economic characteristics. This downward trend is displayed in Figure 3 in the thin solid line with the squares. Judging from the large decreases in the AIC and BIC values from Model 1 to Model 2 to Model 3, the demographic and economic characteristics improved the fit of the models considerably.

In most cases the demographic and economic characteristic variables operate in the expected direction. Higher unemployment and a greater share of the population in the crime-prone age range of 16-29 are associated with higher incarceration, while higher levels of education are associated with lower incarceration. Yet not all variables operate the same for blacks and whites, and not all operate in the expected direction. This is due to controlling for the other variables and to the state fixed effects dummies. Among blacks, greater within-race wage inequality is associated with higher incarceration, but among whites it is associated with lower incarceration. This pattern persists across all of the models, even when other variables are controlled (and is also evident in models that do not include any other state characteristics-models not shown). This pattern in consistent with Wilson's arguments about the concentration of poverty among blacks that accompanied the growth of the black middle class the associated rise in inequality among blacks.

Among blacks, higher wage income at the 25th percentile is associated with higher imprisonment, but among whites it is associated with lower imprisonment. These income effects become more consistent in direction and shrink as other variables are added in later models, suggesting that failing to account for other factors such as migration and urbanization may be driving the unexpected wage income results in Model 3. The percentage of single mothers shows a strong and consistently negative association with both black and white incarceration rates. Bivariate analyses reveal that this unexpected relationship is a product of the state fixed effects in the model (models not shown). Intuitively, this means that once all cross-state variation is removed, there is a negative relationship between single motherhood and incarceration within-states over time.

Model 4 adds the Population Growth, Migration, and Urbanization variables to the model. These variables considerably reduce the base level racial difference in incarceration reflected in the constant as well as the trend between 1960 and 1980. This is also clear from Figure 3, which shows the remaining trend from Model 4 with the dotted line with the triangles. The large decreases in the $\mathrm{BIC}$ and AIC statistics also indicate the importance of these variables for model fit. Moreover, all of the individual variables show associations with incarceration in the expected directions. Percentage black and black population growth both increase black incarceration but decrease white incarceration. Migration (percentage born in another region) and urbanization increase incarceration among both blacks and whites, while agricultural employment is associated with lower levels of incarceration among both blacks and whites. Manufacturing employment is associated with higher levels of incarceration among blacks but not whites. Glancing ahead to Models 5 and 6, we see that these results are robust to further controls for political context and segregation. Together, these results suggest that processes of black population growth, urbanization, and migration played important roles in the trend in the racial difference in incarceration between 1940 and 1980.

Model 5 adds the political context variables to the model. The constant and year coefficients in Table 6 and the trend line in Figure 3 (which shows the remaining trend from Model 5 in the dot-dash line with circles) both reveal that these variables further account for some of the baseline racial difference in 1940 as well as a small fraction of the trend between 1960 and 1970. Both variables operate in the expected direction, with more Republican influence associated with greater incarceration, but this effect is stronger among whites. Indeed, the AIC and BIC statistics actually increase from Model 4 to Model 5 for blacks, suggesting that the political variables are adding little explanatory power to the black model. The white models, however, show decreases in the AIC and BIC, as we 
would expect based on the large coefficients on the political variables in Model 5. These results suggest that the political factors identified in previous research as explaining black incarceration in more recent years are less important in the period we study.

Model 6 adds the segregation measure, which is positively associated with incarceration for both blacks and whites, although not surprisingly the association is considerably larger for blacks than whites. Adding this measure to the model further explains the baseline difference in 1940 and further explains the trends over time, particularly between 1950 and 1960, when migration of blacks from the South to the urban North greatly increased racial segregation. This is clear from the constant and year coefficients in the model and from the resulting trend line in Figure 3, which shows the remaining trend from Model 6 with the dashed line with asterisks. The BIC and AIC statistics for both the black and the white models also suggest that this variable has improved the fit of the model. Note however, that there is still a large racial difference, particularly at baseline, that remains unexplained by the full array of variables in Model 6. We have not fully explained the baseline racial difference in incarceration. Additional research is necessary to fully understand the racial differences in incarceration in the 1940-1980 period.

The above discussion has focused on the coefficients in the models and the residual time trends. It does not explicitly consider the trends in the mean characteristics of blacks and whites. An alternative way to interpret the models in Table 6 is to decompose the trends in racial differences into those that are due to differences in the mean characteristics of blacks and whites and those that are due to differences in the coefficients between blacks and whites. This decomposition will allow us to examine the relative importance of specific variables in driving the changes in the racial difference in incarceration taking into account both the changes in the characteristics over time and the association between the variables and incarceration by racial group. Juhn, Murphy, and Pierce [80] generalize the cross-sectional Blinder-Oaxaca decomposition to two periods (see also Makepeace et al. [81]). Because we estimate only one model pooled across years for each group, we focus here on the trends attributable to changes in the black means and trends attributable to racial differences in changes in mean characteristics. ${ }^{13}$

Table 7 shows the decomposition for the entire period from 1940 to 1980 using the race-specific means from those years (Appendix B provides cross-sectional Blinder-Oaxaca decompositions for 1940 and 1980 individually, and Table B3 displays decompositions that are analogous to the 1940-1980 decomposition in Table 7, separately by decade). Table 7 shows the total raw contribution of each variable and the percentage of the total raw racial trend for which it accounts. The bottom three rows of the table show the sum of the trends captured by the model, the trend that remains unexplained (identical to the B-W 1980 dummy in Model 6 of Table 6), and the resulting sum, which represents the raw trend in the racial difference once race-specific state fixed effects are removed. When interpreting the results of the decompositions, it is important to remember that the results are dependent on the specification of the regression models. For example, if one variable in the model is endogenous to another, the decomposition will attribute the effects to the endogenous variable. This might occur, for example, with the political variables. If election of a Republican governor is a response to an increasing black population, some of the effect of increasing black population will be attributed to the Republican governor variable.

13 Juhn et al. [80] develop a decomposition based on two groups each with separate regressions in each of two time periods. Because we estimate one equation for each racial group that pools all time periods, coefficients are implicitly constrained to be equal within groups across time periods. This means that changes in coefficients are removed from the decomposition, and we focus only on changes in the characteristics of blacks and differential changes by race in mean group characteristics. 
Table 7. Trends in racial difference in $\ln$ (incarceration rate) attributable to changes in mean characteristics.

\begin{tabular}{|c|c|c|}
\hline & \multicolumn{2}{|c|}{ 1940-1980 } \\
\hline & Raw Contribution & Column Percentage \\
\hline Demographic/Economic Characteristics & 0.538 & $1871.9 \%$ \\
\hline Wage Income at 25 th \%tile & -0.151 & $-525.4 \%$ \\
\hline Percentage Single Parent & 0.133 & $464.2 \%$ \\
\hline Unemployment & -0.009 & $-30.4 \%$ \\
\hline Percentage High School Grad & -0.102 & $-353.3 \%$ \\
\hline Percentage Aged 16-29 & 0.088 & $305.8 \%$ \\
\hline Wage Inter-Quartile Range & 0.578 & $2011.1 \%$ \\
\hline Migration/Urbanization & -0.383 & $-1333.9 \%$ \\
\hline Percentage Black & -0.213 & $-741.5 \%$ \\
\hline Black Pop Change & 0.014 & $48.4 \%$ \\
\hline Percentage Born Other Region & 0.061 & $212.2 \%$ \\
\hline Percentage Urban & 0.011 & $39.3 \%$ \\
\hline Percentage Agricultural Workers & -0.121 & $-422.6 \%$ \\
\hline Percentage Manufacturing Workers & -0.135 & $-469.8 \%$ \\
\hline Political & -0.006 & $-20.0 \%$ \\
\hline Republican Governor & -0.016 & $-56.6 \%$ \\
\hline Percentage Pres Votes Republican & 0.011 & $36.6 \%$ \\
\hline Segregation & 0.026 & $90.1 \%$ \\
\hline Dissimilarity Index & 0.026 & $91.0 \%$ \\
\hline Segregation Missing Dummy & 0.000 & $-0.8 \%$ \\
\hline Sum & 0.175 & $608.2 \%$ \\
\hline Trend Unexplained (Year Dummies) & -0.146 & $-508.2 \%$ \\
\hline Raw Trend (net of state fixed effects) & 0.029 & $100.0 \%$ \\
\hline
\end{tabular}

Note: From decomposition based on Model 6 of Table 6. Positive values of raw contribution refer to increase in black incarceration relative to white incarceration.

Note first that we have more than explained the trend in the racial difference in incarceration (the unexplained trend is negative and the sum of the attributable trend is over $100 \%$ ), which was also evident from Figure 3 (recall that the trend line switched from upward to downward). We see from Table 5 which variables explain the increase in the racial difference in incarceration and which explain any countervailing effects that contributed to decreases in the racial difference in incarceration. ${ }^{14}$ Most of the contribution comes from demographic and economic characteristics and the migration and urbanization variables. Although segregation plays a major role in the 1940 and 1980 cross-sectional decompositions (see Appendix B, Table B2), the small contribution of segregation to the trend in the racial difference in incarceration is due to its relatively small change over the period. Political context also appears to play only a minor role in the trend, with its effects concentrated in the 1960s (see Appendix B Table B3 for decade specific results). The small contribution of the political context variables is due to their relatively small coefficients. Overall, the changes in the demographic and economic characteristics serve to increase the racial difference in incarceration over time, though this effect seems concentrated in the 1950s. It also masks multiple countervailing forces. The bulk of the increase in incarceration is attributable to rising wage inequality among blacks relative to whites, particularly in the 1950s and 1960s, and rising rates of single parenthood among blacks relative to whites, particularly in the 1960s and 1970s. Growth in wages among blacks pushed racial differences

14 Note that for variables that are not race specific (percentage black, black pop change, and the political and segregation variables), the changes in white and black means between 1940 and 1980 will be identical, so by definition there is no trend attributable to racial differences in the changes in these means. 
in incarceration downward, particularly in the 1940s, 1950s, and 1960s, as did the rise in education among blacks, particularly in the 1970s.

Overall, the migration and urbanization variables contributed to a decline in the racial difference in incarceration, but again this masks considerable variation by specific variables and across time. Percentage black, percentage in manufacturing, and percentage in agriculture drove the downward trend, while percentage born in another region and, to a much lesser extent, black population change and percentage urban, drove the upward trend. The contribution of percentage black is most pronounced in the 1940s, followed by the 1950s and 1960s. Mean percentage black declines throughout the period (recall that the models are weighted by mean proportion black in the state across years, so this indicates a dispersal of the black population), and percentage black is positively associated with black incarceration and negatively associated with white incarceration. Agricultural employment, which is negatively associated with incarceration for both blacks and whites, declined drastically throughout the period in both groups, but because blacks started with a greater concentration in the agricultural sector, the change was larger for blacks. These effects are concentrated somewhat in the 1940s and 1960s. Manufacturing employment increased among both groups in the 1940s and 1950s but increased among blacks in the 1960s and 1970s while decreasing among whites in those decades. These trends, coupled with a positive association with incarceration among blacks and a negative association with incarceration among whites meant that changes in manufacturing employment fueled an increase in the racial difference in incarceration in the 1950s and decreases in the 1960s and 1970s. Percentage born in another region increased the racial difference in incarceration in the 1950s and 1960s, and to a small extent in the 1970s. During these periods, this measure of migration was much higher for blacks than whites, a difference that was exaggerated by the larger positive association with incarceration among blacks than whites. Differential changes in urbanization decreased the racial difference in incarceration in the 1950s but increased the racial difference during the 1960s, for a slight net upward impact over the whole period.

\section{Conclusions}

The racial difference in incarceration rose dramatically from 1940 to 2000, though the increase appears concentrated in the period between 1940 and 1980. Despite increases in the percentage of federal and state prisoners who were black between 1940 and 1970 that were as large or larger than those after 1970, most research on the racial difference in incarceration has focused on the later period. The bulk of this research has focused on explanations involving discrimination, racial threat, the war on drugs, and political factors. This paper extends the literature on the racial difference in incarceration by (1) examining an earlier and longer time span, the entire period between 1940 and 1980, and by (2) focusing on additional explanatory factors, particularly the roles of population growth, migration between states, and urbanization. We presented three different analyses that approach the racial difference in incarceration between 1940 and 1980 from three different angles. All three indicate the importance of demographic processes.

The accounting model in Part I shows that increases in the black population, black arrest rates and black sentencing rates relative to those of whites account for the bulk of the increase in the RDI between 1940 and 1980. Differential population growth accounts for one third of the trend in RDI. The remaining increase in RDI can be attributed mostly to differential changes in population arrest rates between 1940 and 1960 and to differential changes in sentencing between 1960 and 1980. In other words, racial differences in sentencing are more important leading up to the prison boom, while racial differences in arrests are more important prior to the prison boom. However, in any particular year, differences in black and white arrest rates account for the vast majority of the cross-sectional racial difference in incarceration, net of population. We remind the reader that due to data limitations for the historical period covered by our research, arrest rates reflect both the probability of committing a serious crime and the probability of being arrested for it, and "sentencing" captures being sentenced to prison for a crime, entry into prison for a parole or probation violation, and lengths of prison terms. 
Further research is necessary to separate crime rates from arrests per crime and to separate front-end sentencing and sentence length from back-end sentencing due to parole and probation violations in this period. We also remind the reader of the limitations of the UCR data used to measure arrest, which may not fully capture all arrests. In particular, if arrests among blacks are overstated relative to arrests among whites, then the importance of arrests will be overstated in each period and the importance of sentencing will be understated. Conversely, if arrests among blacks are understated relative to arrests among whites, then the importance of arrests will be overstated and the importance of sentencing will be understated.

Our decomposition of state variation in black and white incarceration rates between 1940 and 1980 in Part II highlights the importance of population change. A rate of population growth greater among blacks than whites in the states where the vast majority of blacks lived accounts for about one-fifth of the increase in the RDI between 1940 and 1980. This analysis also indicates the importance of differential population growth by race in states with different rates of incarceration. These differences in population growth by race, which we believe are mostly due to differential migration between states by race, increased the RDI because they increased the relative proportion of the black population in states with higher incarceration rates for blacks and in states with increasing incarceration rates over time. Differential population increase among blacks in states with higher black incarceration rates accounts for about one-fifth of the RDI, and differential population growth in states with increasing incarceration rates accounts for about one-quarter of RDI. The remaining one-third of the increase in RDI is unexplained by this decomposition.

Our state characteristics model and decomposition in Part III reveal perhaps our most surprising finding: had the demographic and economic characteristics of blacks been the same as those of whites, the racial difference in incarceration would have been even greater during this period and the trend in the racial difference between 1940 and 1980 would have been downward instead of upward. In other words, holding constant demographic and economic characteristics increased the cross-sectional racial difference in incarceration in each year. This was driven by differences in income levels, single parenthood, and the proportion of the population in the prime age for criminal activity (ages 16-29), variables on which whites were significantly more advantaged compared to blacks throughout the period. Larger increases in single parenthood among blacks played a particularly strong role. Controlling for further demographic and economic characteristics also reverses the residual trend in the racial difference in incarceration from upward to downward. This was driven by unemployment, education, and within-race wage inequality, all of which changed more for whites than blacks during this period.

Our state characteristics analyses also indicate the importance of migration, population growth, and urbanization in understanding racial differences in incarceration, as these variables are strongly associated with within-state variation in incarceration rates for both blacks and whites and account for some of the trend in the RDI, particularly between 1960 and 1980. Between 1940 and 1980, blacks disproportionately moved from the South to the North and West and to cities relative to whites, and black employment in manufacturing increased while black employment in agriculture decreased relative to whites. As a result, the black population spread throughout more of the country, and there was considerable black population change throughout the period. The typical black individual in 1980 lived in a state that was less black than the typical black individual in 1940. Overall, changes in percentage black, percentage in manufacturing, and percentage in agriculture drove the RDI downward, while changes in percentage born in another region and, to a much lesser extent, black population change and percentage urban, drove the RDI upward. Segregation, although important for understanding point-in-time racial differences in incarceration, varies too little over time to explain more than a trivial portion of the trend in the RDI.

Our results indicate that political context plays only a minor role in explaining changes in the racial difference in incarceration between 1940 and 1980. Note that this result is entirely consistent with the prior literature by Jacobs and others that focuses on the more recent period. That literature 
argues that the rise of a "law and order" politics laced with racial undertones in the post-Nixon period drove more punitive criminal justice policy led by Republicans. Because we find few effects of Republican strength on the incarceration of blacks in earlier decades, our analysis is consistent with the approximate timing of the political shift emphasized in prior research.

Overall, our analyses suggest a very different set of explanations for changes in the racial differences in incarceration for the period between 1940 and 1980 than for the more recent period, for which the literature has emphasized changes in political power and political processes that led to harsher treatment of blacks by the criminal justice system. The period after World War II was one of considerable social, economic, and demographic change for both blacks and whites, particularly with regard to migration and urbanization. Our analysis shows how these changes are linked to variation over time in the racial difference in incarceration. Our emphasis on population growth in our first two analyses highlights the importance of considering population counts in addition to rates of incarceration. Indeed, the common practice of measuring racial inequality in incarceration with the proportion of the inmate population that is black obscures the role of racial differences in population growth in the RDI.

The analyses in this paper describe the relative importance of different processes in understanding racial differences in incarceration during the post-war period. However, our analysis is largely descriptive, and strong causal claims await more detailed analyses of specific causes and their effects. As such our analysis serves as a guide for areas of further inquiry rather than a definitive account of the social, economic, and political processes that have generated changes in incarceration. For example, the importance of the growth of wage inequality in our third analysis suggests one area for additional research. Further unpacking such historical processes will require a consideration of processes driving both criminal behavior and the responses of the criminal justice system to that behavior as well as considering more carefully than we are able to do here how various forces are linked to one another. For instance, some of the economic and demographic changes we have emphasized (e.g., single motherhood) may well in part be products of other changes (e.g., segregation and urbanization). Similarly, our analysis is not well positioned to make strong distinctions between migration effects and the effects of any racial threat that the increased presence of blacks in Northern cities may have produced. More detailed analyses of trends in specific decades should also consider additional factors that influence the population at risk of incarceration or criminal activity such as rates of juvenile detention, military enlistments and the draft, deaths from drug overdoses, the de-institutionalization of the mentally ill, and executions.

Acknowledgments: This research was supported by the small grants program at the Institute for Research on Poverty at the University of Wisconsin-Madison and by the National Science Foundation through a research grant awarded to Christopher Winship and through a National Science Foundation Graduate Research Fellowship awarded to David Harding, by a National Science Foundation Integrative Graduate Education and Research Traineeship Grant (\#98070661), and by support from the University of Michigan Population Studies Center, which receives funding from the Eunice Kennedy Shriver National Institute for Child and Human Development. Stephen Morgan, Peter Moskos, and Michael Biggs helped with early data collection and analyses. We also thank Amy Cooter for research assistance. We thank Robert Sampson, Anthony Braga, Jeffrey Fagan, and Chris Muller for helpful comments on previous versions of this paper.

Author Contributions: Christopher Winship conceived the study. Christopher Winship and David Harding designed the study. David Harding and Christopher Winship collected and analyzed the data. David Harding and Christopher Winship wrote the paper.

Conflicts of Interest: The authors declare no conflict of interest. The funding sponsors had no role in the design of the study; in the collection, analyses, or interpretation of data; in the writing of the manuscript, and in the decision to publish the results.

\section{Abbreviations}

The following abbreviations are used in this manuscript:

RDI Racial difference in incarceration

FBI Federal Bureau of Investigation 


\section{Appendix A. Supplemental Material for Section 4.1}

Table A1. Population, inmates, arrests, and admissions by race in the United States, 1940-1980.

\begin{tabular}{ccccc}
\hline Year & Population & Arrests & Admissions & Prisoners \\
\hline Whites & & & & \\
\hline 1940 & $118,214,870$ & 155,775 & 43,558 & 152,994 \\
1950 & $134,942,028$ & 230,985 & 42,204 & 115,124 \\
1960 & $158,831,732$ & 609,445 & 56,985 & 139,765 \\
1970 & $177,748,975$ & $1,380,684$ & 43,203 & 114,608 \\
1980 & $188,372,000$ & $2,005,034$ & 102,639 & 143,259 \\
\hline Blacks & & & & \\
1940 & $12,865,518$ & 58,730 & 19,497 & 64,925 \\
1950 & $15,042,286$ & 103,193 & 18,769 & 61,470 \\
1960 & $18,871,831$ & 320,149 & 26,359 & 82,935 \\
1970 & $22,580,289$ & 711,975 & 32,122 & 80,742 \\
1980 & $26,495,000$ & 922,218 & 69,743 & 133,926 \\
\hline
\end{tabular}

Sources: U.S. Census [75] (Population, Prisoners); Langan [7] (Admissions), FBI UCR [82,83] (Arrests). Notes: UCR arrests are for Part 1 Index crimes plus drug crimes and are inflated by inverse of population coverage ratio; 1940 and 1950 UCR arrests are based on fingerprint cards submitted to the FBI and likely understate arrests to some degree.

Table A2. Intermediate calculations for Figure 2.

\begin{tabular}{|c|c|c|c|c|c|c|}
\hline & Arrests/Population & Adm/Arrest & $\begin{array}{c}\text { Ln } \\
\text { (Prisoners) }\end{array}$ & $\begin{array}{l}\text { Adjusted } \\
\text { for Pop }\end{array}$ & $\begin{array}{l}\text { Adjusted for Pop \& } \\
\text { Arrests/Pop }\end{array}$ & $\begin{array}{c}\text { Adjusted for Pop \& } \\
\text { Arrests/Pop \& } \\
\text { Adm/Arrest }\end{array}$ \\
\hline \multicolumn{7}{|l|}{ Whites } \\
\hline 1940 & 0.001 & 0.280 & 11.938 & -6.650 & -0.018 & 1.256 \\
\hline 1950 & 0.002 & 0.183 & 11.654 & -7.067 & -0.696 & 1.003 \\
\hline 1960 & 0.004 & 0.094 & 11.848 & -7.036 & -1.473 & 0.897 \\
\hline 1970 & 0.008 & 0.031 & 11.649 & -7.347 & -2.489 & 0.976 \\
\hline 1980 & 0.011 & 0.051 & 11.872 & -7.182 & -2.639 & 0.333 \\
\hline \multicolumn{7}{|l|}{ Blacks } \\
\hline 1940 & 0.005 & 0.332 & 11.081 & -5.289 & 0.100 & 1.203 \\
\hline 1950 & 0.005 & 0.182 & 11.026 & -5.500 & -0.518 & 1.186 \\
\hline 1960 & 0.017 & 0.082 & 11.326 & -5.427 & -1.351 & 1.146 \\
\hline 1970 & 0.032 & 0.045 & 11.299 & -5.634 & -2.177 & 0.922 \\
\hline \multirow[t]{2}{*}{1980} & 0.035 & 0.076 & 11.805 & -5.287 & -1.929 & 0.652 \\
\hline & \multicolumn{2}{|c|}{ Black/White Ratio } & \multicolumn{4}{|c|}{ Black-White } \\
\hline 1940 & 3.464 & 1.187 & -0.857 & 1.361 & 0.118 & -0.053 \\
\hline 1950 & 4.008 & 0.995 & -0.627 & 1.567 & 0.178 & 0.183 \\
\hline 1960 & 4.421 & 0.881 & -0.522 & 1.608 & 0.122 & 0.249 \\
\hline 1970 & 4.059 & 1.442 & -0.350 & 1.713 & 0.312 & -0.054 \\
\hline 1980 & 3.270 & 1.477 & -0.067 & 1.894 & 0.709 & 0.319 \\
\hline
\end{tabular}

Notes: italicized values appear in Figure 2. Adjusted for Pop $=\ln (\mathrm{P})-\ln ($ Pop $)$. Adjusted for Pop \& Arrests/Pop $=\ln (\mathrm{P})-\ln ($ Pop $)-\ln ($ Arr $/$ Pop $)$. Adjusted for Pop \& Arrests $/$ Pop \& Adm $/$ Arrest $=\ln (\mathrm{P})-\ln ($ Pop $)-$ $\ln ($ Arr $/$ Pop $)-\ln$ (Adm/Arrest). Black -White subtracts white value for year from black value for year. 


\section{Appendix B. Supplemental Material for Section 4.3}

Table B1. Black population weighted state variable means by race, 1940-1980.

\begin{tabular}{|c|c|c|c|c|c|}
\hline & 1940 & 1950 & 1960 & 1970 & 1980 \\
\hline \multicolumn{6}{|l|}{ Inmates } \\
\hline Black & 4563 & 4019 & 6085 & 6319 & 9575 \\
\hline White & 5960 & 5585 & 7903 & 7760 & 9260 \\
\hline Black-White & -1397 & -1566 & -1817 & -1441 & 315 \\
\hline \multicolumn{6}{|l|}{ In(Inmates) } \\
\hline Black & 8.29 & 8.14 & 8.51 & 8.55 & 8.96 \\
\hline White & 8.37 & 8.30 & 8.66 & 8.61 & 8.89 \\
\hline Black-White & -0.08 & -0.16 & -0.15 & -0.06 & 0.08 \\
\hline \multicolumn{6}{|l|}{ Pop } \\
\hline Black & 700,929 & 728,099 & 869,906 & $1,072,848$ & $1,254,094$ \\
\hline White & $3,320,809$ & $4,377,569$ & $5,800,952$ & $7,121,010$ & $7,340,457$ \\
\hline Black-White & $-2,619,880$ & $-3,649,470$ & $-4,931,047$ & $-6,048,162$ & $-6,086,363$ \\
\hline \multicolumn{6}{|l|}{$\ln ($ Pop $)$} \\
\hline Black & 13.28 & 13.35 & 13.54 & 13.72 & 13.87 \\
\hline White & 14.73 & 15.00 & 15.28 & 15.51 & 15.58 \\
\hline Black-White & -1.45 & -1.65 & -1.75 & -1.79 & -1.71 \\
\hline \multicolumn{6}{|l|}{$\ln ($ inmates/pop) } \\
\hline Black & -4.99 & -5.21 & -5.03 & -5.17 & -4.90 \\
\hline White & -6.35 & -6.70 & -6.62 & -6.90 & -6.69 \\
\hline Black-White & 1.36 & 1.49 & 1.60 & 1.73 & 1.79 \\
\hline \multicolumn{6}{|c|}{ Wage Income 25 th \%tile (thousands) } \\
\hline Black & $\$ 2.93$ & $\$ 6.36$ & $\$ 9.05$ & $\$ 13.65$ & $\$ 13.49$ \\
\hline White & $\$ 5.39$ & $\$ 10.27$ & $\$ 15.53$ & $\$ 20.68$ & $\$ 18.81$ \\
\hline Black-White & $-\$ 2.46$ & $-\$ 3.90$ & $-\$ 6.48$ & $-\$ 7.03$ & $-\$ 5.32$ \\
\hline \multicolumn{6}{|l|}{$\%$ Single Mothers } \\
\hline Black & $17.5 \%$ & $18.1 \%$ & $21.7 \%$ & $31.4 \%$ & $41.0 \%$ \\
\hline White & $7.1 \%$ & $6.1 \%$ & $6.6 \%$ & $8.7 \%$ & $11.7 \%$ \\
\hline Black-White & $10.4 \%$ & $12.0 \%$ & $15.2 \%$ & $22.7 \%$ & $29.3 \%$ \\
\hline \multicolumn{6}{|c|}{ Unemployment Rate } \\
\hline Black & $10.3 \%$ & $6.2 \%$ & $8.6 \%$ & $6.0 \%$ & $12.0 \%$ \\
\hline White & $6.9 \%$ & $3.0 \%$ & $4.1 \%$ & $3.1 \%$ & $5.3 \%$ \\
\hline Black-White & $3.5 \%$ & $3.3 \%$ & $4.4 \%$ & $2.9 \%$ & $6.7 \%$ \\
\hline \multicolumn{6}{|c|}{$\%$ High School Grad } \\
\hline Black & $6.0 \%$ & $10.8 \%$ & $17.4 \%$ & $28.9 \%$ & $50.5 \%$ \\
\hline White & $22.9 \%$ & $30.2 \%$ & $39.6 \%$ & $51.5 \%$ & $66.9 \%$ \\
\hline Black-White & $-16.9 \%$ & $-19.5 \%$ & $-22.2 \%$ & $-22.6 \%$ & $-16.4 \%$ \\
\hline \multicolumn{6}{|l|}{$\%$ age $16-29$} \\
\hline Black & $26.2 \%$ & $23.3 \%$ & $18.7 \%$ & $22.1 \%$ & $27.6 \%$ \\
\hline White & $25.7 \%$ & $22.0 \%$ & $18.4 \%$ & $21.9 \%$ & $24.8 \%$ \\
\hline Black-White & $0.5 \%$ & $1.3 \%$ & $0.2 \%$ & $0.1 \%$ & $2.9 \%$ \\
\hline \multicolumn{6}{|c|}{ Wage IQR (thousands) } \\
\hline Black & $\$ 3.99$ & $\$ 5.81$ & $\$ 8.23$ & $\$ 10.94$ & $\$ 14.16$ \\
\hline White & $\$ 9.70$ & $\$ 9.50$ & $\$ 12.96$ & $\$ 16.48$ & $\$ 18.48$ \\
\hline Black-White & $-\$ 5.71$ & $-\$ 3.69$ & $-\$ 4.73$ & $-\$ 5.54$ & $-\$ 4.32$ \\
\hline
\end{tabular}


Table B1. Cont.

\begin{tabular}{|c|c|c|c|c|c|}
\hline & 1940 & 1950 & 1960 & 1970 & 1980 \\
\hline \multicolumn{6}{|l|}{$\%$ Black } \\
\hline Black & $24.0 \%$ & $20.1 \%$ & $17.7 \%$ & $16.1 \%$ & $16.9 \%$ \\
\hline White & $24.0 \%$ & $20.1 \%$ & $17.7 \%$ & $16.1 \%$ & $16.9 \%$ \\
\hline Black-White & - & - & - & - & - \\
\hline \multicolumn{6}{|l|}{ Black Pop Change } \\
\hline Black & $8.6 \%$ & $28.0 \%$ & $30.9 \%$ & $23.7 \%$ & $17.5 \%$ \\
\hline White & $8.6 \%$ & $28.0 \%$ & $30.9 \%$ & $23.7 \%$ & $17.5 \%$ \\
\hline Black-White & - & - & - & - & - \\
\hline \multicolumn{6}{|c|}{ \% Born Other Region } \\
\hline Black & $12.9 \%$ & $18.8 \%$ & $18.9 \%$ & $17.3 \%$ & $19.9 \%$ \\
\hline White & $5.6 \%$ & $8.6 \%$ & $10.9 \%$ & $12.4 \%$ & $15.6 \%$ \\
\hline Black-White & $7.3 \%$ & $10.2 \%$ & $8.0 \%$ & $4.9 \%$ & $4.3 \%$ \\
\hline \multicolumn{6}{|l|}{ \% Urban } \\
\hline Black & $40.6 \%$ & $51.7 \%$ & $58.8 \%$ & $70.4 \%$ & $80.9 \%$ \\
\hline White & $36.1 \%$ & $45.7 \%$ & $46.6 \%$ & $61.0 \%$ & $69.7 \%$ \\
\hline Black-White & $4.4 \%$ & $6.0 \%$ & $12.2 \%$ & $9.3 \%$ & $11.2 \%$ \\
\hline \multicolumn{6}{|c|}{$\%$ Agricultural Employment } \\
\hline Black & $36.7 \%$ & $23.8 \%$ & $14.8 \%$ & $6.0 \%$ & $2.3 \%$ \\
\hline White & $26.4 \%$ & $15.7 \%$ & $7.1 \%$ & $3.7 \%$ & $2.9 \%$ \\
\hline Black-White & $10.3 \%$ & $8.1 \%$ & $7.7 \%$ & $2.3 \%$ & $-0.6 \%$ \\
\hline \multicolumn{6}{|c|}{ \% Manufacturing Employment } \\
\hline Black & $6.4 \%$ & $14.8 \%$ & $16.4 \%$ & $22.0 \%$ & $22.0 \%$ \\
\hline White & $20.0 \%$ & $23.9 \%$ & $27.3 \%$ & $25.5 \%$ & $22.0 \%$ \\
\hline Black-White & $-13.6 \%$ & $-9.1 \%$ & $-11.0 \%$ & $-3.5 \%$ & $0.1 \%$ \\
\hline \multicolumn{6}{|c|}{ Republican Governor } \\
\hline Black & $17.7 \%$ & $20.6 \%$ & $9.5 \%$ & $43.5 \%$ & $39.8 \%$ \\
\hline White & $17.7 \%$ & $20.6 \%$ & $9.5 \%$ & $43.5 \%$ & $39.8 \%$ \\
\hline Black-White & - & - & - & - & - \\
\hline \multicolumn{6}{|c|}{$\%$ Republican Votes } \\
\hline Black & $24.9 \%$ & $31.0 \%$ & $46.1 \%$ & $39.3 \%$ & $46.0 \%$ \\
\hline White & $24.9 \%$ & $31.0 \%$ & $46.1 \%$ & $39.3 \%$ & $46.0 \%$ \\
\hline Black-White & - & - & - & - & - \\
\hline \multicolumn{6}{|c|}{ Dissimilarity Index } \\
\hline Black & 0.68 & 0.75 & 0.76 & 0.77 & 0.72 \\
\hline White & 0.68 & 0.75 & 0.76 & 0.77 & 0.72 \\
\hline Black-White & - & - & - & - & - \\
\hline \multicolumn{6}{|c|}{ Dissimilarity Missing } \\
\hline Black & $0.2 \%$ & $16.6 \%$ & $5.0 \%$ & $0.0 \%$ & $0.0 \%$ \\
\hline White & $0.2 \%$ & $16.6 \%$ & $5.0 \%$ & $0.0 \%$ & $0.0 \%$ \\
\hline Black-White & - & - & - & - & - \\
\hline
\end{tabular}

Notes: Includes 39 states with nontrivial black populations. Both black and white means are weighted by the proportion of the national black population living in the state in each year. Third row is blank for variables that are identical for blacks and whites by definition.

In this Appendix we perform a standard Blinder-Oaxaca decomposition of log incarceration rates separately in 1940 and 1980 to examine the sources of the racial difference in each year based on the estimates from Model 6 in Table 4. This type of decomposition simulates how the dependent variable (log incarceration rate) would change had whites had the same X's (same characteristics) as blacks and had the white equation had the same coefficients as the black equation. Table B2 displays the results of 
these decompositions. For each year, total contributions ("racial difference attributable") are divided into those due to race differences in means and those due to race differences in coefficients. The middle column for each year shows the percentage of the racial difference in that year attributable to racial differences in the means in each variable. The rightmost column for each year shows the percentage of the racial difference in that year attributable to racial differences in the coefficients. The leftmost column for each year is the sum of the middle and rightmost columns and also shows column sums by category of variable. Positive values indicate a contribution to the widening of the racial difference while negative values indicate that a variable narrows the racial difference. The bottom row shows the percentage of the overall difference that is not explained in each year, as captured by the constant and year dummies in the models. We see immediately that, consistent with the results in Table 6 and graphically displayed in Figure 3, in both 1940 and 1980 some of the variables in our model contribute to a widening racial difference and some serve to narrow this difference. In addition, in both years there is still a considerable remaining cross-sectional racial difference, which is also consistent with the results in Table 6 and Figure 3.

Consider first the racial difference in 1940. Controlling for the demographic and economic characteristics increases the black-white difference by 27 percentage points in 1940. In other words, had whites had the same demographic and economic characteristics as blacks and had the white coefficients been the same as black coefficients, the racial difference in incarceration would have been considerably larger. This is driven primarily by single parenthood, percentage aged 16-29, and wage inequality. For single parenthood, the contribution is evenly divided between differences attributable to different means and differences attributable to different coefficients (blacks had higher rates of single parenthood in 1940 but smaller effects of single parenthood on incarceration). The contribution of percentage aged 16-29 is largely driven by differences in coefficients (a higher number of individuals in this age group is associated with greater incarceration among whites but less incarceration among blacks). The contribution of wage inequality is mostly driven by differences in means (blacks have lower wage inequality than whites), but this effect is somewhat counterbalanced by the contribution of racial differences in coefficients (wage inequality is positively associated with incarceration among blacks but negatively associated with incarceration among whites).

Together, the migration and urbanization variables explain less than one percent of the racial difference in 1940. However upon closer inspection, this combined figure masks two countervailing forces, percentage black and the industry variables. Percentage in agricultural employment and percentage in manufacturing employment serve to narrow the racial difference in 1940. Had whites had the same means as blacks on these variables, the racial difference in incarceration would have been considerably higher (in 1940 whites were more likely than blacks to be employed in manufacturing and less likely to be employed in agriculture). In contrast, percentage black contributes to a widening of the racial gap. Because percentage black is positively associated with incarceration among blacks and negatively associated with incarceration among whites, equalizing those coefficients would lower the racial difference in incarceration. Political variables appear to play no role in 1940, but segregation seems to play a major role, explaining over $23 \%$ of the racial gap. This also reflects differences in the segregation coefficient between blacks and whites. While segregation is positively associated with incarceration for both groups, the association for blacks is about double that for whites. Were whites to have the black coefficient, the racial gap in incarceration would be considerably smaller in 1940. 
Table B2. Decomposition of Single Year Racial Difference in Ln(Incarceration Rate), Black-White, 1940 and 1980.

\begin{tabular}{|c|c|c|c|c|c|c|}
\hline & \multicolumn{3}{|c|}{1940} & \multicolumn{3}{|c|}{1980} \\
\hline & $\begin{array}{l}\text { Racial Difference } \\
\text { Attributable }\end{array}$ & $\begin{array}{c}\text { Difference } \\
\text { Attributable to } \\
\text { Means }\end{array}$ & $\begin{array}{l}\text { Difference } \\
\text { Attributable to } \\
\text { Coefficients }\end{array}$ & $\begin{array}{l}\text { Racial Difference } \\
\text { Attributable }\end{array}$ & $\begin{array}{c}\text { Difference } \\
\text { Attributable to } \\
\text { Means }\end{array}$ & $\begin{array}{l}\text { Difference } \\
\text { Attributable to } \\
\text { Coefficients }\end{array}$ \\
\hline Demographic/Economic Characteristics & $-26.62 \%$ & & & $-9.83 \%$ & & \\
\hline Wage Income at 25 th $\%$ tile & $1.46 \%$ & $-1.11 \%$ & $2.57 \%$ & $-7.89 \%$ & $-2.06 \%$ & $-5.83 \%$ \\
\hline Percent Single Parent & $-7.06 \%$ & $-3.44 \%$ & $-3.62 \%$ & $-10.69 \%$ & $-8.33 \%$ & $-2.36 \%$ \\
\hline Unemployment & $-1.71 \%$ & $-0.58 \%$ & $-1.13 \%$ & $-2.81 \%$ & $-0.96 \%$ & $-1.84 \%$ \\
\hline Percent High School Grad & $-2.60 \%$ & $-2.57 \%$ & $-0.03 \%$ & $-6.74 \%$ & $-2.14 \%$ & $-4.61 \%$ \\
\hline Percent Age 16-29 & $-5.61 \%$ & $-0.52 \%$ & $-5.09 \%$ & $-5.10 \%$ & $-2.60 \%$ & $-2.50 \%$ \\
\hline Wage IQR & $-11.11 \%$ & $-15.38 \%$ & $4.27 \%$ & $23.41 \%$ & $-10.02 \%$ & $33.42 \%$ \\
\hline Migration/Urbanization & $-0.81 \%$ & & & $5.87 \%$ & & \\
\hline Percent Black & $8.09 \%$ & - & $8.09 \%$ & $-2.82 \%$ & - & $-2.82 \%$ \\
\hline Black Pop Change & $0.71 \%$ & - & $0.71 \%$ & $1.25 \%$ & - & $1.25 \%$ \\
\hline Percent Born Other Region & $0.03 \%$ & $2.64 \%$ & $-2.61 \%$ & $0.97 \%$ & $1.35 \%$ & $-0.37 \%$ \\
\hline Percent Urban & $-0.59 \%$ & $1.51 \%$ & $-2.09 \%$ & $3.96 \%$ & $3.27 \%$ & $0.69 \%$ \\
\hline Percent Agricultural Workers & $-3.08 \%$ & $-4.00 \%$ & $0.92 \%$ & $-0.93 \%$ & $0.20 \%$ & $-1.13 \%$ \\
\hline Percent Manufacturing Workers & $-5.96 \%$ & $-8.54 \%$ & $2.58 \%$ & $3.44 \%$ & $0.03 \%$ & $3.41 \%$ \\
\hline Political & $0.00 \%$ & & & $-0.26 \%$ & & \\
\hline Republican Governor & $0.33 \%$ & - & $0.33 \%$ & $-0.46 \%$ & - & $-0.46 \%$ \\
\hline Percent Pres Votes Republican & $-0.33 \%$ & - & $-0.33 \%$ & $0.20 \%$ & - & $0.20 \%$ \\
\hline Segregation & $23.39 \%$ & & & $21.34 \%$ & & \\
\hline Dissimilarity Index & $23.39 \%$ & - & $23.39 \%$ & $21.34 \%$ & - & $21.34 \%$ \\
\hline Segregation Missing Dummy & $0.00 \%$ & - & $0.00 \%$ & $0.00 \%$ & - & $0.00 \%$ \\
\hline Sum & $-4.04 \%$ & $-31.98 \%$ & $27.94 \%$ & $17.12 \%$ & $-21.26 \%$ & $38.38 \%$ \\
\hline Unexplained Difference & $104.04 \%$ & & & $82.88 \%$ & & \\
\hline
\end{tabular}

Notes: based on Model 6 of Table 6; cells are percent of raw difference (net of fixed effects) by year; Positive values indicate higher black incarceration rate relative to white. 
Table B3. Trends in Racial Difference in Ln(Incarceration Rate) Attributable to Changes in Mean Characteristics, by Period.

\begin{tabular}{|c|c|c|c|c|c|c|c|c|c|c|}
\hline & \multicolumn{2}{|c|}{ 1940-1950 } & \multicolumn{2}{|c|}{ 1950-1960 } & \multicolumn{2}{|c|}{ 1960-1970 } & \multicolumn{2}{|c|}{ 1970-1980 } & \multicolumn{2}{|c|}{ 1940-1980 (Total) } \\
\hline & $\begin{array}{c}\text { Raw } \\
\text { Contribution }\end{array}$ & $\begin{array}{l}\text { Row } \\
\text { Percent }\end{array}$ & $\begin{array}{c}\text { Raw } \\
\text { Contribution }\end{array}$ & $\begin{array}{l}\text { Row } \\
\text { Percent }\end{array}$ & $\begin{array}{c}\text { Raw } \\
\text { Contribution }\end{array}$ & $\begin{array}{c}\text { Row } \\
\text { Percent }\end{array}$ & $\begin{array}{c}\text { Raw } \\
\text { Contribution }\end{array}$ & $\begin{array}{c}\text { Row } \\
\text { Percent }\end{array}$ & $\begin{array}{c}\text { Raw } \\
\text { Contribution }\end{array}$ & $\begin{array}{l}\text { Column } \\
\text { Percent }\end{array}$ \\
\hline Demographic/Economic Characteristics & -0.039 & $-7.2 \%$ & 0.431 & $80.1 \%$ & 0.088 & $16.3 \%$ & 0.058 & $10.8 \%$ & 0.538 & $1871.9 \%$ \\
\hline Wage Income at 25 th \%tile & -0.051 & $34.1 \%$ & -0.047 & $31.2 \%$ & -0.063 & $41.4 \%$ & 0.010 & $-6.6 \%$ & -0.151 & $-525.4 \%$ \\
\hline Percent Single Parent & 0.006 & $4.5 \%$ & 0.021 & $16.0 \%$ & 0.055 & $40.9 \%$ & 0.052 & $38.6 \%$ & 0.133 & $464.2 \%$ \\
\hline Unemployment & -0.048 & $548.4 \%$ & 0.018 & $-206.7 \%$ & -0.018 & $203.3 \%$ & 0.039 & $-445.0 \%$ & -0.009 & $-30.4 \%$ \\
\hline Percent High School Grad & -0.009 & $9.2 \%$ & -0.014 & $13.3 \%$ & -0.026 & $25.6 \%$ & -0.053 & $51.8 \%$ & -0.102 & $-353.3 \%$ \\
\hline Percent Age 16-29 & 0.182 & $206.7 \%$ & 0.143 & $162.8 \%$ & -0.162 & $-183.7 \%$ & -0.075 & $-85.7 \%$ & 0.088 & $305.8 \%$ \\
\hline Wage Inter-quartile Range & -0.118 & $-20.3 \%$ & 0.309 & $53.5 \%$ & 0.301 & $52.1 \%$ & 0.086 & $14.8 \%$ & 0.578 & $2011.1 \%$ \\
\hline Migration/Urbanization & -0.127 & $33.2 \%$ & -0.032 & $8.4 \%$ & -0.148 & $38.7 \%$ & -0.076 & $19.7 \%$ & -0.383 & $-1333.9 \%$ \\
\hline Percent Black & -0.119 & $55.8 \%$ & -0.071 & $33.4 \%$ & -0.048 & $22.7 \%$ & 0.025 & $-11.9 \%$ & -0.213 & $-741.5 \%$ \\
\hline Black Pop Change & 0.030 & $216.3 \%$ & 0.005 & $32.9 \%$ & -0.011 & $-80.0 \%$ & -0.010 & $-69.3 \%$ & 0.014 & $48.4 \%$ \\
\hline Percent Born Other Region & -0.008 & $-12.5 \%$ & 0.025 & $40.3 \%$ & 0.027 & $44.1 \%$ & 0.017 & $28.1 \%$ & 0.061 & $212.2 \%$ \\
\hline Percent Urban & 0.006 & $50.8 \%$ & -0.039 & $-341.3 \%$ & 0.042 & $373.1 \%$ & 0.002 & $17.5 \%$ & 0.011 & $39.3 \%$ \\
\hline Percent Agricultural Workers & -0.035 & $28.8 \%$ & -0.018 & $15.0 \%$ & -0.045 & $37.3 \%$ & -0.023 & $18.9 \%$ & -0.121 & $-422.6 \%$ \\
\hline Percent Manufacturing Workers & -0.002 & $1.2 \%$ & 0.067 & $-49.4 \%$ & -0.113 & $83.4 \%$ & -0.088 & $64.9 \%$ & -0.135 & $-469.8 \%$ \\
\hline Political & 0.001 & $-16.9 \%$ & 0.016 & $-272.3 \%$ & -0.028 & $495.5 \%$ & 0.006 & $-106.4 \%$ & -0.006 & $-20.0 \%$ \\
\hline Republican Governor & -0.002 & $12.9 \%$ & 0.008 & $-50.2 \%$ & -0.025 & $154.2 \%$ & 0.003 & $-16.9 \%$ & -0.016 & $-56.6 \%$ \\
\hline Percent Pres Votes Republican & 0.003 & $29.2 \%$ & 0.007 & $71.0 \%$ & -0.003 & $-32.2 \%$ & 0.003 & $32.0 \%$ & 0.011 & $36.6 \%$ \\
\hline Segregation & 0.070 & $268.7 \%$ & -0.008 & $-30.6 \%$ & -0.004 & $-14.0 \%$ & -0.032 & $-124.1 \%$ & 0.026 & $90.1 \%$ \\
\hline Dissimilarity Index & 0.047 & $178.1 \%$ & 0.008 & $32.2 \%$ & 0.003 & $12.7 \%$ & -0.032 & $-123.0 \%$ & 0.026 & $91.0 \%$ \\
\hline Segregation Missing Dummy & 0.023 & $-9983.2 \%$ & -0.016 & $7069.6 \%$ & -0.007 & $3013.6 \%$ & 0.000 & $0.0 \%$ & 0.000 & $-0.8 \%$ \\
\hline Sum & -0.095 & $-54.5 \%$ & 0.407 & $232.5 \%$ & -0.093 & $-53.0 \%$ & -0.044 & $-25.0 \%$ & 0.175 & $608.2 \%$ \\
\hline Trend Unexplained (Year Dummies) & -0.134 & $91.9 \%$ & -0.160 & $109.7 \%$ & 0.103 & $-70.2 \%$ & 0.046 & $-31.4 \%$ & -0.146 & $-508.2 \%$ \\
\hline Raw Trend (net of state fixed effects) & -0.230 & $-798.7 \%$ & 0.246 & $857.0 \%$ & 0.010 & $34.4 \%$ & 0.002 & $7.4 \%$ & 0.029 & $100.0 \%$ \\
\hline
\end{tabular}

Note: From decomposition based on Model 6 of Table 6; positive values of raw contribution refer to increase in black incarceration relative to white incarceration. 
Turning to the breakdown of the racial difference in 1980, we see that the demographic and economic characteristics combined reduce the racial difference by about $10 \%$. However, again there are important countervailing factors, as wage inequality operates in the opposite direction and by itself increases by over $23 \%$ the racial difference in incarceration. Again this is a product of the differing associations between wage inequality and incarceration by group. Though whites have higher within-group wage inequality in 1980, inequality is positively associated with incarceration among blacks and negatively associated with inequality among whites. If whites had the same mean inequality as blacks, the racial difference in incarceration would be smaller by 10 percentage points. Racial differences in single motherhood, income from wages, education, and percentage aged 18-29 play a significant role in reducing the racial difference in incarceration. Combined, the migration and urbanization variables serve to increase the racial differences in incarceration in 1980, although again there are countervailing effects, as percentage urban and percentage in manufacturing increase the racial difference while percentage black reduces the racial difference. In other words, had whites had the same association between segregation and incarceration as blacks, the racial difference in incarceration would have been larger. Had whites had the same means and coefficients as blacks on percentage urban and percentage in manufacturing, the racial difference in incarceration would have been smaller. For percentage in manufacturing, racial differences in means had all but disappeared by 1980 , so this contribution is driven largely by differences in coefficients. The political variables again seem to play little role, and the differential effects of segregation are again very important, accounting for over $21 \%$ of the racial difference in 1980 .

\section{References}

1. Pew Center on the States. One in 100: Behind Bars in America 2008. Washington: Pew Charitable Trusts, 2008.

2. Western, Bruce. Punishment and Inequality in America. New York: Russell Sage, 2006.

3. Mauer, Marc. Race to Incarcerate. New York: New Press, 1999.

4. Garland, David W., ed. Mass Imprisonment: Social Causes and Consequences. New York: Sage, 2001.

5. Wacquant, Loic. "Deadly symbiosis: When ghetto and prison meet and mesh." Punishment E Society 3 (2001): 95-134. [CrossRef]

6. Tonry, Michael. Malign Neglect: Race, Crime, and Punishment in America. New York: Oxford University Press, 1995.

7. Langan, Patrick A. Race of Prisoners Admitted to State and Federal Institutions, 1926-1986. Washington: U.S. Department of Justice, Office of Justice Programs, Bureau of Justice Statistics, 1991.

8. Smith, James D., and Finis Welch. Forty Years of Economic Progress for Blacks. Santa Monica: Rand Corporation, 1986.

9. Farley, Reynolds. Blacks and Whites: Narrowing the Gap? Cambridge: Harvard University Press, 1984.

10. Jaynes, Gerald D., and Robin M. Williams. A Common Destiny: Blacks and American Society. Washington: National Academy Press, 1989.

11. Cohen, Jacqueline, and Jose Canela-Cacho. “Incarceration and Violent Crime: 1965-1988." In Understanding and Preventing Violence, Vol. IV, Report of Panel on the Understanding and Control of Violent Behavior. Edited by Albert J. Reiss, Jr. and Jeffrey A. Roth. Washington: National Academy Press, 1994.

12. United States Bureau of the Census. Statistical Abstracts of the United States. Washington: US Government Printing Office, 1925.

13. Tolnay, Stewart E. "The African American 'Great Migration' and Beyond." Annual Review of Sociology 29 (2003): 209-32. [CrossRef]

14. Sorensen, Jon, Robert Hope, and Don Stemen. "Racial Disproportionality in State Prison Admissions: Can Regional Variation be explained by differential arrest rates? " Journal of Criminal Justice 31 (2003): 73-84. [CrossRef]

15. Mann, Coramae R. Unequal Justice: A Question of Color (Blacks in the Diaspora). Bloomington and Indianapolis: Indiana University Press, 1993.

16. Kleck, Gary. "Racial Discrimination in Criminal Sentencing: Evaluation of Evidence with Additional Evidence on the Death Penalty." American Sociological Review 46 (1981): 783-805. [CrossRef]

17. Hawkins, Darnell. F. "Trends in Black-White Imprisonment: Changing Conceptions of Race or Changing Patterns of Social Control? " Crime and Social Justice 24 (1985): 187-209. 
18. Hawkins, Darnell F. "Beyond Anomalies: Rethinking the Conflict Perspective on Race and Criminal Punishment." Social Forces 65 (1987): 719-45. [CrossRef]

19. Sabol, William J. "Racially Disproportionate Prison Populations in the United States." Contemporary Crisis 13 (1989): 405-32. [CrossRef]

20. Muller, Christopher. "Northward Migration and the Rise of Racial Disparity in American Incarceration, 1880-1950." American Journal of Sociology 118 (2011): 281-326. [CrossRef]

21. Duster, Troy. "Crime, Youth Unemployment, and the Black Urban Underclass." Crime \& Delinquency 33 (1987): 300-16. [CrossRef]

22. Cogan, John F. “The Decline of Black Teenage Employment: 1950-1970.” American Economic Review 72 (1982): 621-38.

23. Mare, Robert D., and Christopher Winship. "The Paradox of Lessening Racial Inequality and Joblessness among Black Youth: Enrollment, Enlistment, and Employment, 1964-1981." American Sociological Review 49 (1984): 39-55. [CrossRef]

24. Wilson, William J. The Truly Disadvantaged. Chicago: Chicago University Press, 1987.

25. Parker, Karen F. Unequal Crime Decline: Theorizing Race, Urban Inequality, and Criminal Violence. New York: NYU Press, 2008.

26. Sampson, Robert J. "Urban Black Violence: The Effect of Male Joblessness and Family Disruption." American Journal of Sociology 93 (1987): 342-82. [CrossRef]

27. Myers, Samuel L., Jr., and William J. Sabol. "Unemployment and Racial Differences in Imprisonment." The Review of Black Political Economy 16 (1987): 189-209. [CrossRef]

28. Cappell, Charles L., and Gresham Sykes. "Prison Commitments, Crime, and Unemployment: A Theoretical and Empirical Specification for the United States, 1933-1985." Journal of Quantitative Criminology 7 (1991): 155-99. [CrossRef]

29. Raphael, Steven, and Rudolf Winter-Ebmer. "Identifying the Effect of Unemployment on Crime." Journal of Law and Economics 44 (2001): 259-83. [CrossRef]

30. Massey, Douglas, and Nancy Denton. American Apartheid: Segregation and the Making of an Underclass. Cambridge: Harvard University Press, 1993.

31. Krivo, Lauren J., Ruth D. Peterson, and Danielle D. Payne. "Segregation, Racial Structure, and Neighborhood Crime." American Journal of Sociology 114 (2009): 1765-902. [CrossRef]

32. Vélez, María, Lauren J. Krivo, and Ruth D. Peterson. "Structural Inequality and Homicide: An Assessment of the Black-White Gap in Killings." Criminology 41 (2003): 645-72. [CrossRef]

33. Krivo, Lauren J., and Ruth D. Peterson. "The Structural Context of Homicide: Accounting for Racial Differences in Process." American Sociological Review 65 (2000): 547-59. [CrossRef]

34. McNulty, Thomas L., and Paul E. Bellair. "Explaining Racial and Ethnic Differences in Serious Adolescent Violent Behavior." Criminology 41 (2003): 709-48. [CrossRef]

35. Sampson, Robert J., Stephen W. Raudenbush, and Felton Earls. "Neighborhoods and Violent Crime: A Multilevel Study of Collective Efficacy." Science 277 (1997): 918-24. [CrossRef] [PubMed]

36. Crutchfield, Robert D., Ross Matsueda, and Kevin Drakulich. "Race, Labor Markets and Neighborhood Violence." In The Many Colors of Crime. Edited by Ruth Peterson, Lauren Krivo and John Hagan. New York: NYU Press, pp. 199-220.

37. Sampson, Robert J., Jeffrey D. Morenoff, and Stephen W. Raudenbush. "Social Anatomy of Racial and Ethnic Disparities in Violence." American Journal of Public Health 95 (2005): 224-32. [CrossRef] [PubMed]

38. Shihadeh, Edward S., and Nicole Flynn. "Segregation and Crime: The Effect of Black Social Isolation on the Rates of Black Urban Violence." Social Forces 74 (1996): 1325-52. [CrossRef]

39. Morris, Martina, and Bruce Western. "U.S. Earnings Inequality at the Close of the 20th Century." Annual Review of Sociology 25 (1999): 623-57. [CrossRef]

40. LaFree, Gary, and Kriss A. Drass. "The Effect of Changes in Intraracial Inequality and Educational Attainment on Changes in Arrest Rates For African Americans and Whites, 1957-1990." American Sociological Review 61 (1996): 614-34. [CrossRef]

41. Jacobs, David, and Ronald Helms. "Towards a Political Model of Incarceration: A Time-Series Examination of Multiple Explanations for Prison Admission Rates." American Journal of Sociology 102 (1996): 323-57. [CrossRef] 
42. Jacobs, David, and Richard Kleban. "Political Institutions, Minorities, and Punishment: A Pooled Cross-National Analysis of Imprisonment Rates." Social Forces 82 (2003): 725-55. [CrossRef]

43. Jacobs, David, and Amber Richardson. "Economic Inequality and Homicide from 1975 to 1995: A Cross-National Fixed-Effects Test." Homicide Studies 12 (2008): 28-45. [CrossRef]

44. Garfinkel, Irving, and Sara S. McLanahan. Single Mothers and Their Children: A New American Dilemma. Washington: Urban Institute Press, 1986.

45. Ensminger, Margaret E., Sheppard G. Kellam, and Barnett R. Rubin. "School and Family Origins of Delinquency: Comparisons by Sex." In Antecedents of Aggression and Antisocial Behavior. Edited by Katherine T. Van Dusen and Sarnoff A. Mednick. Boston: Kluwer-Nijhoff, 1983.

46. LaFree, Gary, Eric Baumer, and Robert O'Brien. "Still separate and unequal? A city-level analysis of the black-white gap in homicide arrests since 1960." American Sociological Review 75 (2010): 75-100. [CrossRef]

47. Gottschalk, Marie. The Prison and the Gallows: The Politics of Mass Incarceration in America. New York: Cambridge University Press, 2006.

48. Wacquant, Loic. Punishing the Poor: The Neoliberal Government of Social Insecurity. London: Duke University Press, 2009.

49. Murakawa, Naomi. The First Civil Right: How Liberals Built Prison America. New York: Oxford University Press, 2014.

50. Lerman, Amy, and Vesla M. Weaver. "Race and Crime in American Politics: From Law and Order to Willie Horton and Beyond." In Oxford Handbook of Race, Ethnicity, Immigration, and Crime. Edited by Sandra M. Bucerius and Michael Tonry. New York: Oxford University Press, 2014, pp. 41-69.

51. Weaver, Vesla M. "Frontlash: Race and the Development of Punitive Crime Policy." Studies in American Political Development 21 (2007): 230-65. [CrossRef]

52. Forman, James, Jr. "Racial Critiques of Mass Incarceration: Beyond the New Jim Crow." New York University Law Review 87 (2012): 101-46.

53. Fortner, Michael J. "The 'Silent Majority' in Black and White: Invisibility and Imprecision in the Historiography of Mass Incarceration." Journal of Urban History 40 (2013): 252-82. [CrossRef]

54. Weaver, Vesla M. "Embedding Crime Policy: The Law Enforcement Assistance Administration and the Growth of the Carceral State." In Living Legislation: Durability, Change and the Politics of American Lawmaking. Edited by Jeffrey A. Jenkins and Eric M. Patashnik. Chicago: Univesity of Chicago Press, 2012, pp. 221-51.

55. Blumstein, Alan. "Racial Disproportionality of the U.S. Prison Populations Revisited." University of Colorado Law Review 64 (1993): 743-60.

56. Blumstein, Alan. "On the Racial Disproportionality of United States' Prison Populations." Journal of Criminal Law and Criminology 73 (1982): 1259-81. [CrossRef]

57. Sampson, Robert J., and John H. Laub. "Structural Variations in Juvenile Court Processing: Inequality, the Underclass, and Social Control." Law \& Society Review 27 (1993): 285-311. [CrossRef]

58. Feeley, Malcolm M., and Jonathan Simon. "The New Penology: Notes on the Emerging Strategy of Corrections and Its Implications." Criminology 30 (1992): 449-74. [CrossRef]

59. Jencks, Christopher. "Is Violent Crime Increasing?" The American Prospect 4 (1991): 98-109.

60. Langan, Patrick A. "Racism on Trial: New Evidence to Explain the Racial Composition of Prisons in the United States." Journal of Criminal Law and Criminology 76 (1985): 666-83. [CrossRef]

61. Blumstein, Alan, and Alan J. Beck. "Population Growth in U.S. Prisons, 1980-1996." In Crime and Justice: A Review of the Research 26 (Prisons). Edited by Michael Tonry and Joan Petersilia. Chicago: University of Chicago Press, 1999, pp. 17-61.

62. Jacobs, David, and Aubrey L. Jackson. "On the Politics of Imprisonment: A Review of Systematic Findings." Annual Review of Law and Social Science 6 (2010): 129-49. [CrossRef]

63. Kent, Stephanie L., and David Jacobs. "Minority Threat and Police Strength From 1980 to 2000: A Fixed-Effects Analysis of Nonlinear and Interactive Effects in Large U.S. Cities." Criminology 43 (2005): 731-60. [CrossRef]

64. Greenberg, David, and Valerie West. "State Prison Populations and Their Growth, 1971-1991." Criminology 39 (2001): 615-53. [CrossRef]

65. Keen, Bradley, and David Jacobs. "Racial Threat, Partisan Politics, and Racial Disparities in Prison Admissions: A Panel Analysis." Criminology 47 (2009): 209-38. [CrossRef]

66. Eitle, David, Stewart D'Alessio, and Lisa Stolzenberg. "Racial Threat and Social Control: A Test of the Political, Economic, and Threat of Black Crime Hypotheses." Social Forces 81 (2002): 557-76. [CrossRef] 
67. Jacobs, David, Jason T. Carmichael, and Stephanie L. Kent. “Vigilantism, Current Racial Threat, and Death Sentences." American Sociological Review 70 (2005): 656-77. [CrossRef]

68. Jacobs, David, and Daniel Tope. "The Politics of Resentment in the Post Civil-Rights Era: Minority Threat, Homicide, and Ideological Voting in Congress." American Journal of Sociology 112 (2007): 1458-94. [CrossRef]

69. LaFree, Gary, Robert O'Brien, and Eric Baumer. "Is the gap between black and white arrest rates narrowing? National trends for personal contact crimes, 1960 to 2002." In The Color of Crime. Edited by Ruth Peterson, Lauren Krivo and John Hagan. New York: New York University Press, 2006, pp. 179-98.

70. Stucky, Thomas D., Karen Heimer, and Joseph B. Lang. "Partisan Politics, Electoral Competition, and Imprisonment: An Analysis of States Over Time." Criminology 43 (2005): 211-48. [CrossRef]

71. Lynch, James P., and Lynn A. Addington, eds. Understanding Crime Statistics: Revisiting the Divergence of the NCVS and the UCR. Cambridge: Cambridge University Press, 2006.

72. Greene, William H. Econometric Analysis, 4th ed. New York: Prentice-Hall, 2000.

73. Blinder, Alan. "Wage Discrimination: Reduced Form and Structural Estimates." Journal of Human Resources 8 (1973): 436-65. [CrossRef]

74. Oaxaca, Ronald. "Male-Female Wage Differentials in Urban Labor Markets." International Economic Review 14 (1973): 693-709. [CrossRef]

75. United States Bureau of the Census. Decennial Censuses of Population and Housing, 1940-1980. Washington: United States Bureau of the Census, 1940-1980.

76. Inter-University Consortium for Political and Social Research. Candidate Name and Constituency Totals, 1788-1990, 5th ed. Ann Arbor: Inter-University Consortium for Political and Social Research, 1995.

77. Cutler, Daniel M., Edward L. Glaeser, and Jacob L. Vigdor. "The Rise and Decline of the American Ghetto." Journal of Political Economy 107 (1999): 455-506. [CrossRef]

78. Raphael, Steven. "The Deinstitutionalization of the Mentally Ill and Growth of the US Prison Population, 1971 to 1996." 2000. Available online: http:/ / ist-socrates.berkeley.edu/ raphael/raphael2000.pdf (accessed on 14 July 2016).

79. Raphael, Seven, and Michael A. Stoll. "Assessing the contribution of the deinstitutionalization of the mentally ill to growth in the U.S. incarceration rate." The Journal of Legal Studies 42 (2013): 187-222. [CrossRef]

80. Juhn, Chinhui, Kevin Murphy, and Brooks Pierce. "Wage Inequality and the Rise in Returns to Skill." Journal of Political Economy 101 (1993): 410-42. [CrossRef]

81. Makepeace, Gerald, Pierella Paci, Heather Joshi, and Peter Dolton. "How Unequally Has Equal Pay Progressed since the 1970s? A Study of Two British Cohorts." The Journal of Human Resources 34 (1999): 534-56. [CrossRef]

82. United States Department of Justice, Federal Bureau of Investigation. Uniform Crime Reports [United States], 1930-1959. ICPSR03666-v1. Ann Arbor: Inter-university Consortium for Political and Social Research, 2003.

83. United States Department of Justice, Federal Bureau of Investigation. Uniform Crime Reporting Program Data: Arrests by Age, Sex, and Race, 1983. ICPSR23326-v2. Ann Arbor: Inter-university Consortium for Political and Social Research, 2014.

(C) 2016 by the authors; licensee MDPI, Basel, Switzerland. This article is an open access article distributed under the terms and conditions of the Creative Commons Attribution (CC-BY) license (http://creativecommons.org/licenses/by/4.0/). 